\title{
México 2020, una democracia débil y asediada
}

\section{Mexico, a weak and surrounded democracy}

\author{
Juan Mario Solis Delgadillo (iD
}

Universidad Autónoma de San Luis Potosí

juan.solis@uaslp.mx

\section{Fernando Barrientos del Monte}

Universidad de Guanajuato

f.barrientos@ugto.mx

\begin{abstract}
Resumen
¿Cuál es el estado de la democracia en México? Es sistémicamente débil y es asediada por al menos cinco peligros: (a) deslizamientos autoritarios, (b) deficiente representación política, (c) corrupción, (d) ineficiencia gubernamental y (e) crimen organizado. El objetivo de este artículo es, por un lado, rastrear los orígenes de esta compleja situación, que devienen de una transición a la democracia centrada en reformas electorales que resultan en poca eficiencia institucional, y por otro lado, mostrar cuánto ha cambiado esto (o no) bajo el primer gobierno 'de izquierda' en el país. Los gobiernos que se han sucedido desde el año 2000, primero encabezados por el PAN (2000-2006 y 2006-2012) y luego por el PRI (20122108), marcados por un contexto de pluralismo moderado, se caracterizaron por su baja incidencia en las relaciones de poder tanto formales como informales, así como por un pobre desempeño en los mecanismos de integración social, sobre todo en el ámbito educativo y laboral. El arribo en 2018 del primer gobierno 'de izquierda' -tardio, en comparación con el resto de América Latina- significó un rechazo abierto a los partidos políticos tradicionales, pero se basó en un liderazgo 'movimentista' y altamente personalista, lo que profundizó las deficiencias de la débil democracia mexicana
\end{abstract}

Palabras clave: Democracia, debilidad institucional, pluralismo limitado, movimentismo, elecciones.

\begin{abstract}
What is the state of democracy in Mexico? It is systemically weak and beset by at least five risks: (a) authoritarianism, (b) deficient political representation, (c) corruption, (d) government inefficiency, and (e) organized crime. The aim of this article is, on the one hand, to trace the origins of this complex situation, which derives from a transition to democracy centred on electoral reforms that result in a lack institutional efficiency, and on the other hand, to show how much this has trasnformed (or not) under the first 'leftist' government in the country. The governments that have succeeded each other since 2000, first led by the PAN (2000-2006 and 2006-2012) and then by the PRI (2012-2108), marked by a context of moderate pluralism, were characterized by their low effectiveness on both formal and informal power relations, as well as by low performance on social integration mechanisms, especially in the education and labor spheres. The arrival in 2018 of the first 'leftist' government - overdue in comparison with the rest of Latin America - meant an open rejection of traditional political parties, but it was based on a 'movementist' and highly personalist leadership, which deepened the deficiencies of Mexico's weak democracy.
\end{abstract}

Keywords: Democracy, institutional weakness, limited pluralism, movimentism, elections.

Articulo: Recibido el 30 de mayo de 2020 y aprobado el 19 de junio de 2020

\section{Cómo citar este artículo:}

Solís, JM. \& Barrientos F. (2020). México 2020, una democracia débil y asediada. Reflexión política 22(45), pp. 80102. doi: https://doi.org/10.29375/01240781.3922 


\section{Introducción}

La democracia en México de los últimos veinte años ha estado asediada por al menos cinco amenazas: deslizamientos autoritarios desde el poder ejecutivo, corrupción en prácticamente todas las esferas de la sociedad, débil representación política, ineficiencia gubernamental y crimen organizado. Los orígenes de esta situación se encuentran en una transición a la democracia centrada en reformas electorales, pero con pocas mejoras en términos de eficiencia institucional. Los gobiernos que se han sucedido desde el año 2000 se han caracterizado por su falta de interés en mejorar las relaciones entre las élites políticas y la desestructuración de los mecanismos sociales de integración, sobre todo en el ámbito educativo y laboral. El arribo del primer gobierno 'de izquierda' en México en 2018 llegó en el momento que ya había sucedido el auge del giro a la izquierda en América Latina, que inició con la llegada de Hugo Chávez al poder en Venezuela en 1999 y los subsecuentes gobiernos en otros países, hasta el final del periodo de Michelle Bachelet en Chile en 2018.

El Movimiento de Regeneración Nacional (MORENA) y su líder Andrés Manuel López Obrador llegaron al poder con las condiciones que ningún otro gobierno de la era democrática había tenido: un gobierno unificado; con mayoría absoluta tanto en la Cámara de senadores como en la de diputados, ganó también la gubernatura de la Ciudad de México -sede de los poderes federales- así como otras seis gubernaturas subnacionales más.

En las dos primeras décadas del siglo XX se esperaba que México avanzara en la consolidación de la democracia, pero los indicadores muestran que esto ha sido un proceso inacabado y con riesgos de involución democrática. Este es uno de los factores que impulsaron el cambio de signo político en las elecciones del 2018, no solo en la presidencia, sino en ambas cámaras del Congreso y en algunos gobiernos estatales. Desde que finalizó el proceso revolucionario iniciado en 1910, el sistema político mexicano ha girado en torno a la figura presidencial. En 1929 se creó un partido hegemónico (el Partido Revolucionario Institucional, PRI) que gobernó hasta el año 2000, y si bien la transición pretendía suprimir las prácticas arraigadas en setenta y un años de gobiernos priístas, el sistema de partidos no logró consolidar una nueva cultura política centrada en el pluralismo (Alcántara, 2008; Solís et al., 2017). Muy al contrario, se generó un proceso de "cartelización" del sistema de partidos; es decir, se hicieron más dependientes de los recursos públicos (Katz y Mair, 1995). A partir de la reforma electoral de 1996, los partidos no solo recibían financiamiento federal sino también estatal, y el monto de los recursos crecía con cada nueva elección (Díaz, 2019). Las reglas electorales poco se modificaron, y cuando lo hicieron se introdujeron nuevos mecanismos como la reelección, las cuotas y la paridad, las candidaturas independientes y algunos mecanismos de democracia directa, pero se dejaron fuera las demandas de representación indígena que se habían expresado desde la década de 1990, así como las demandas del fortalecimiento del federalismo, cuyos movimientos habían empujado la transición a la democracia. Con respecto al sistema presidencial, no se modificaron en gran medida las facultades del poder ejecutivo, por lo que, en términos reales, el presidente permanecía como el principal actor sobre el cual gira la agenda política del país. De allí que la evaluación de la democracia en México pase necesariamente por el análisis del desempeño del poder ejecutivo. Aunque evidentemente no es el único factor, sí es uno de los más relevantes en el sistema político mexicano.

¿Cómo explicar la debilidad de la democracia mexicana y cuáles son sus perspectivas a futuro? Una de las preocupaciones intelectuales y académicas en los años setenta del siglo pasado en México -y toda América Latina- era el proceso de transformación de los regímenes políticos. La discusión se cernía en las posibilidades de transición hacia el socialismo o hacia la democracia. El problema era identificar las coaliciones políticas que catalizaran, movilizaran y encausaran el proceso, así como las posibles trayectorias de la transformación. Gran parte de la literatura política en la región apostaba a que los cambios podrían sucederse a partir de grandes movimientos sociales, incluso armados, pero la desaparición en esos años de las opciones orientadas al socialismo real abrió la brecha para favorecer la democracia. Esto sucedió, en términos de Giorgio Alberti (1991), 'por default': ante la falta de alternativas, 
la democracia quedó como la única vía para salir de los autoritarismos de la época, pero no era necesariamente la opción buscada y deseada por todos los sectores políticos y sociales.

Entre los obstáculos de la democratización está la pervivencia del movimentismo, una forma de comportamiento político colectivo que se caracteriza por la presencia de un líder carismático que trata de articular todos los intereses de la comunidad política, pero con una gran interdependencia vertical y horizontal, lo que genera una fuerte lealtad y solidaridad, así como un permanente rechazo al movimiento y un enemigo externo. El movimentismo, según Alberti (1991), se basa en juegos de suma-cero y se traduce en una lógica de amigo/enemigo. La transición a la democracia en América Latina, como en otras regiones del mundo, fue un proceso pero al mismo tiempo se superpusieron los problemas económicos generados por la globalización y la invisibilización de los problemas de las clases sociales. Ello generó la fragmentación de la sociedad civil y la desarticulación y desorganización de las instituciones estatales.

La lógica del movimentismo se impuso tanto a nivel macro como micro ante la imposibilidad de reconocer las legitimas aspiraciones de los sectores que participaron marginalmente en la democratización. Esta dinámica es la que explicaría en parte la difícil consolidación de la democracia, dando lugar a una serie de adjetivaciones: "democracias delegativas", "autoritarismos competitivos", "democracias iliberales", "democracias semiconsolidadas", etc. En suma, lo que existen son regimenes híbridos (Morlino, 2008). México se encuentra en este conjunto de regímenes, pues persisten prácticas autoritarias que conviven con instituciones democráticas, y por ello, aquí se califica su democracia como débil. Se han construido instituciones para la democracia pero que funcionan ambiguamente, sobre todo porque persiste una constante ausencia del Estado de derecho que hace difícil la consolidación de la democracia (Aguiar, 2015). Esta condición de régimen híbrido, probablemente más democrático que autoritario, hace a la figura del presidente el factor central que inclina la balanza entre seguir el proceso de democratización o fomentar prácticas autoritarias sin modificar las reglas, pues la ambigüedad de las instituciones lo permite.

La hibridación tiene al menos tres consecuencias observables. Primero, una persistente cultura antipolítica, es decir, una baja identificación con los principios y las instituciones democráticas, lo que fomenta el ascenso de los políticos outsiders y el discurso antipolítico. Segundo, una lógica antipartidista, fundada en prácticas políticas orientadas a denostar a los partidos políticos y promover la aparición de movimientos como modelos de participación, pero dependientes de fuertes liderazgos personales. Y tercero, la lógica de Robin Hood: los gobernantes que llegan al poder fomentando la antipolítica y el antipartidismo, aprovechan el descontento social para implementar políticas distributivas que no son negativas por sí mismas, pero que ignoran las reglas formales del sistema político haciendo ineficiente las estructuras de gobierno, pero generando aceptación social. Este artículo muestra una panorámica de los elementos que caracterizan la debilidad de la democracia en México, así como el asedio que sufre por deslizamientos populistas y autoritarios.

Inicialmente se hace un balance de la correlación de fuerzas políticas a partir de las elecciones del 2018 y el triunfo del primer gobierno de izquierda en México. A continuación se analizan las condiciones políticas previas que fueron debilitando el sistema de partidos, sobre todo las fallas en el ejercicio del poder presidencial y la insuficiente transformación de las reglas de la forma de gobierno más allá de los aspectos electorales, lo que explica la irrupción en la arena político electoral de un líder con rasgos populistas cobijado por un movimiento. Posteriormente se elabora un diagnóstico de los primeros meses del gobierno de López Obrador, quien se ha caracterizado por un discurso de confrontación permanente, pero sobre todo por sus políticas populistas y deslizamientos autoritarios. Al final se concluye que la democracia mexicana es débil porque su transición centrada en aspectos electorales no trastocó los cimientos del régimen. Así, permanecieron ciertas prácticas autoritarias políticas que solo se diferencian del color partidista, pero que asedian a la democracia al igual que el populismo autoritario.

\section{La correlación de fuerzas en México 2018-2020}

Al igual que la mayoría de las democracias en América Latina, México ha experimentado signos inequívocos de malestar social en los últimos años. Previo a los comicios generales de 2018 la ciudadanía mexicana manifestaba su descontento con la corrupción explícita, la alta percepción de 
violencia e inseguridad, la marcada asimetría en la distribución de la riqueza, las escasas expectativas de justicia, las bajas tasas de creación de empleos y los altos índices de pobreza y desigualdad.

Las esperanzas puestas en la democracia años atrás -que posibilitó primero la alternancia a nivel subnacional y la caída del otrora hegemónico PRI, finalmente en el año 2000- se fueron diluyendo dado que los resultados de la política no se tradujeron en mejores condiciones de vida en los planos económico y social (Díaz y León, 2019). Como sostiene Manuel Alcántara (2020) para el conjunto de las democracias latinoamericanas, este malestar encontró su origen en distintas fuentes que con el tiempo se han vuelto insoportables para la ciudadanía, en buena medida por los valores culturales del neoliberalismo, valores que han potenciado respuestas individuales y egoístas en confrontación con las lógicas tradicionales de la política (p. 538).

En un contexto de imperante corrupción, violencia fuera de control y mediocre crecimiento económico, los comicios del 2018 se presentaron como un momento propicio para discutir entre dos proyectos con visiones opuestas sobre la realidad del país (Carrera y Solís, 2012; Moreno Brid y Ros, 2018; Levy, 2018) (ver Tabla 1). Martínez Hernández (2020), destaca que dicho esquema de competencia planteó el debate entre la continuidad y estabilidad de la política económica instaurada desde la década de 1990 y el cambio del sistema político que quedó inconcluso tras la primera alternancia en la Presidencia de la República en el año 2000 (p.369). Dos ingredientes fundamentales para entender el clima político de ese momento han sido la polarización y la personalización de la política, situación de la que sacó ventaja López Obrador, el opositor más visible de los tres últimos presidentes mexicanos: Vicente Fox (2000-2006), Felipe Calderón (2006-2012) y Enrique Peña Nieto (2012-2018).

López Obrador, un habilidoso y perseverante

Tabla 1. Comportamiento de diferentes indicadores sociales durante el gobierno de Enrique Peña Nieto (2012-2018).

\begin{tabular}{|c|c|c|c|c|c|c|c|c|}
\hline Indicador & 2012 & 2013 & 2014 & 2015 & 2016 & 2017 & 2018 & 2019 \\
\hline $\begin{array}{l}\text { Crecimiento del PIB (\% } \\
\text { anual) }\end{array}$ & 3.64 & 1.35 & 2.8 & 3.29 & 2.92 & 2.07 & 1.99 & 0.1 \\
\hline Índice de Gini & 45.4 & - & 45.8 & - & 43.4 & - & 45.4 & - \\
\hline Pobreza (\%) & 45.5 & - & 46.2 & - & 43.6 & - & 41.9 & - \\
\hline Pobreza extrema (\%) & 9.8 & - & 9.5 & - & 7.6 & - & 7.4 & - \\
\hline $\begin{array}{c}\text { Desempleo } \\
\text { (\% población activa) }\end{array}$ & 4.89 & 4.91 & 4.81 & 4.31 & 3.86 & 3.42 & 3.32 & 3.4 \\
\hline Tasa de homicidios & 19 & 19 & 17 & 17 & 20 & 26 & 26 & 28 \\
\hline
\end{tabular}

Fuente: Adaptación de la tabla elaborada por Martínez Hernández (2020, p. 360) con base en datos del INEGI y CONEVAL

político con rasgos de populista de los que "pegan hacia arriba”, es decir, hacia las élites económicas y sociales (Casullo, 2019, p. 25), entendió mejor que nadie que el 2018 representaba la oportunidad más favorable para llegar al poder. Con un discurso antagonista, capaz de dividir las aguas entre un "nosotros" popular y un "ellos" (las élites enemigas), López Obrador logró posicionar lo que Casullo (p. 70-71) define como los protagonistas del mito populista: un líder (él), un héroe (el pueblo de México) y un villano ("La mafia del poder"); una simplificación extremadamente eficaz en contextos de desilusión general.

Tras las elecciones de 2012 que perdió frente al candidato del PRI, Enrique Peña Nieto, López Obrador rompió con el Partido de la Revolución Democrática (PRD) y emprendió una senda para convertir a su movimiento, MORENA, en un partido hecho a su medida, mismo que logró su registro en el año 2014 y participó por primera vez en las elecciones legislativas de 2015, obteniendo 7\% de los escaños de la Cámara de Diputados. Con una estructura a su servicio y una realidad que "evidenciaba rasgos de declive y desgaste institucional, social y político" (Martínez, 2020, p. 360), López Obrador fue capaz de acaparar el debate público al controlar la agenda y el pulso 
de la opinión pública frente a sus oponentes, que en todo momento le persiguieron muy por detrás en la contienda.

Lo cierto es que López Obrador aprovechó las coyunturas críticas y fue él mismo un combustible para la polarización política y social, cuyos niveles en 2018 solo son comparables con los vistos durante y después del proceso electoral del 2006, cuando perdió esas elecciones por un escaso margen del 0.6\% frente a Felipe Calderón (Partido Acción Nacional). López Obrador calificó a los comicios como fraudulentos, señalamientos que nunca pudo probar (Tello, 2007; Ugalde, 2008), pero que quedaron entre sus seguidores como una verdad incuestionable. A ello se suman una serie de acontecimientos escandalosos que ocurrieron a lo largo de la administración 2012-2018, tales como: la Casa Blanca del presidente Peña Nieto, la Estafa Maestra, el Socavón de Cuernavaca, los casos de corrupción asociados a gobernadores priistas, la matanza de Tlatlaya o los desaparecidos de Ayotzinapa. Las condiciones para un cambio de rumbo político estaban más que dadas.

La contienda electoral se disputó entre cinco candidaturas, cuatro hombres y una mujer, cuyos perfiles, tanto etarios como de formación académica y trayectoria política, eran muy disímiles entre sí (Cuadro 1). No obstante, en lo que sí existió una coincidencia fue en la inclinación de todos ellos en el eje de valores (conservadurismo-liberalismo) en el que mostraron una clara propensión hacia el conservadurismo, lo que en buena medida delinea el perfil de los electores mexicanos cuyas preferencias no suelen estar tan determinadas por la diatriba ideológica como sí por los discursos valorables.

El 1 de julio de 2018 se celebraron las elecciones y López Obrador venció de manera contundente en las urnas al obtener $53,19 \%$ de los votos, $30 \%$ por encima de su más cercano

Cuadro 1. Perfiles y trayectorias de los candidatos a la presidencia de México en 2018

\begin{tabular}{|c|c|c|c|c|}
\hline Candidato & $\begin{array}{c}\text { Año de } \\
\text { nacimiento }\end{array}$ & $\begin{array}{l}\text { Partido o } \\
\text { coalición }\end{array}$ & $\begin{array}{l}\text { Nivel de } \\
\text { estudios }\end{array}$ & Trayectoria politica \\
\hline Ricardo Anaya Cortés & 1979 & $\begin{array}{l}\text { Por México al } \\
\text { Frente }\end{array}$ & Doctorado & $\begin{array}{c}\text { Diputado local (2009-2011) } \\
\text { Diputado federal (2012-2015) } \\
\text { Presidente del PAN (2014-2017) }\end{array}$ \\
\hline $\begin{array}{c}\text { José Antonio Meade } \\
\text { Kuribreña }\end{array}$ & 1969 & $\begin{array}{l}\text { Todos por } \\
\text { México }\end{array}$ & Doctorado & $\begin{array}{c}\text { Secretario de Energía (2011) } \\
\text { Secretario de Hacienda } \\
(2011-2012 \text { y 2016-2017) } \\
\text { Secretario de Relaciones Exteriores (2012-2015) } \\
\text { Secretario de Desarrollo Social (2015-2016) }\end{array}$ \\
\hline $\begin{array}{c}\text { Andrés Manuel López } \\
\text { Obrador }\end{array}$ & 1953 & $\begin{array}{c}\text { Juntos Haremos } \\
\text { Historia }\end{array}$ & Licenciatura & $\begin{array}{c}\text { Presidente del PRD (1996-1999) } \\
\text { Jefe de Gobierno de la Ciudad de México (2000-2005) } \\
\text { Presidente de MORENA (2014-2017) } \\
\text { Candidato presidencial }(2006,2012)\end{array}$ \\
\hline $\begin{array}{c}\text { Jaime Heliodoro } \\
\text { Rodríguez Calderón }\end{array}$ & 1957 & Independiente & Licenciatura & $\begin{array}{c}\text { Diputado federal (1991-1994) } \\
\text { Diputado local (1997-2000) } \\
\text { Presidente municipal de García, Nuevo León } \\
\text { (2009-2012) } \\
\text { Gobernador de Nuevo León (2015-2021) }\end{array}$ \\
\hline $\begin{array}{c}\text { Margarita Zavala Gómez } \\
\text { del Campo }\end{array}$ & 1967 & Independiente & Licenciatura & $\begin{array}{l}\text { Diputada local (1994-1997) } \\
\text { Diputada federal (2003-2006) }\end{array}$ \\
\hline
\end{tabular}

Fuente: Elaboración propia con base en la información recopilada por Martínez (2020, p. 367) y en www.margaritazavala.com

competidor, que fue el candidato de la alianza PANPRD-MC, Ricardo Anaya, quien obtuvo 22,28\% de las preferencias. Muy por detrás quedaron el candidato del PRI, José Antonio Meade y el independiente Jaime Rodríguez Calderón, quienes solo lograron captar 16,41\% y 5,23\%, respectivamente (INE, 2018).
López Obrador logró vencer en todos los estados de la República con excepción de Guanajuato, un histórico bastión conservador en manos del PAN desde la década de 1990.

El magnetismo de la imagen de López Obrador, aunado a un discurso que bregaba por 
desterrar la corrupción, la desmilitarización del país, anteponer las necesidades de los pobres por sobre otras prioridades y la promesa de crecimiento del PIB anual al $4 \%$, por citar solo algunos de los ítems más importantes de su campaña, conllevó, a su vez, al arrastre de millones de votos que favorecieron a cientos de candidatos de la coalición Juntos Haremos Historia.

En la Cámara de Diputados, la coalición de partidos que encolumnaron a López Obrador logró por sí sola abarcar las dos terceras partes de las bancas. Posteriormente, tras una serie de deserciones en el grupo parlamentario del PRD y la enésima reconversión del Partido Verde Ecologista de México (PVEM) ${ }^{2}$, el bloque oficialista consiguió una cómoda mayoría calificada que le ha permitido impulsar reformas constitucionales sin resistencias (Tabla 2). En el Senado de la República existe el único dique de contención al poder que las urnas otorgaron al movimiento lopezobradorista, pues ahí la oposición se ha logrado articular de mejor manera al ser conscientes que cuentan con los votos suficientes para impedir que MORENA y sus aliados alcancen la mayoría calificada (Tabla 3).

Tras más de veinte años de Congresos divididos en los que ningún partido había ostentado una mayoría absoluta -lo que obligaba a la negociación y consenso por parte de los diferentes

Tabla 2. Composición porcentual de la Cámara de Diputados (1994-2018).

\begin{tabular}{|c|c|c|c|c|c|c|c|c|c|}
\hline Partidos & 1994 & 1997 & 2000 & 2003 & 2006 & 2009 & 2012 & 2015 & 2018 \\
\hline PRI & 60.0 & 47.8 & 42.2 & 45.0 & 20.8 & 47.4 & 42.6 & 40.6 & 9.4 \\
\hline PAN & 23.8 & 24.0 & 41.2 & 30.4 & 41.2 & 28.6 & 22.8 & 21.8 & 15.6 \\
\hline PRD & 14.2 & 25.2 & 10.0 & 19.2 & 25.2 & 14.2 & 20.6 & 12.2 & 2.2 \\
\hline PT & 2.0 & 1.4 & 1.6 & 1.0 & 3.2 & 2.6 & 3.0 & - & 6.8 \\
\hline PVEM & - & 1.6 & 3.4 & 3.4 & 3.8 & 4.2 & 5.6 & 9.4 & 2.6 \\
\hline $\mathrm{MC}$ & - & - & 0.6 & 1.0 & 3.2 & 1.2 & 3.4 & 5.0 & 5.6 \\
\hline PANAL & - & - & - & - & 1.8 & 1.8 & 2.0 & 2.2 & - \\
\hline MORENA & - & - & - & - & - & - & - & 7.0 & 51.9 \\
\hline PES & - & - & - & - & - & - & - & 1.6 & 5.0 \\
\hline Otros & - & - & 1.0 & - & 0.8 & - & - & 0.2 & 0.8 \\
\hline
\end{tabular}

Fuente: Elaboración propia con base en datos del INE, el Sistema de Información Legislativa (SIL) y Martínez (2020).

Tabla 3. Composición porcentual de la Cámara de Senadores (1994-2018).

\begin{tabular}{cccccc} 
Partidos & $\mathbf{1 9 9 4}$ & $\mathbf{2 0 0 0}$ & $\mathbf{2 0 0 6}$ & $\mathbf{2 0 1 2}$ & $\mathbf{2 0 1 8}$ \\
\hline PRI & 60.2 & 46.9 & 25.8 & 42.2 & $\mathbf{1 0 . 9}$ \\
\hline PAN & 25.8 & 35.9 & 40.6 & 29.7 & $\mathbf{1 8 . 8}$ \\
\hline PRD & 12.5 & 12.5 & 22.7 & 17.2 & $\mathbf{2 . 3}$ \\
\hline PT & 0.8 & - & 1.6 & 3.9 & $\mathbf{4 . 7}$ \\
\hline PVEM & 0.8 & 3.9 & 4.7 & 5.5 & $\mathbf{5 . 5}$ \\
\hline MC & - & 0.6 & 3.9 & 0.8 & $\mathbf{7 . 0}$ \\
\hline PANAL & - & - & 0.8 & 0.8 & - \\
\hline MORENA & - & - & - & - & $\mathbf{4 6 . 1}$ \\
\hline PES & - & - & - & - & $\mathbf{3 . 9}$ \\
\hline Otros & - & 0.8 & - & - & $\mathbf{0 . 8}$
\end{tabular}

Fuente: Elaboración propia con base en datos del INE, el Sistema de Información Legislativa (SIL) y Martínez (2020).

${ }^{2}$ EI PVEM se ha caracterizado por ser un partido acomodaticio frente a los vaivenes de la política nacional, al menos en los últimos veinte años, desde la primera alternancia política en la Presidencia de la República, cuando apoyó la candidatura de Vicente Fox. Más adelante se convirtió en aliado del PRI y, en la actualidad, del gobierno de Andrés Manuel López Obrador. Basta con mencionar que es un partido repudiado y expulsado de la Internacional Verde por las contradicciones programáticas e ideológicas en las que se ha visto envuelto, como cuando en 2009 promovía la protección de los animales, por un lado, y la pena de muerte a secuestradores, por el otro (El Universal, 2009). 
actores de la política nacional-, la dinámica del sistema de partidos dio un vuelco tras la elección del 2018, pues modificó la forma de construir la política en los espacios de decisión, solo comparable con los años previos a 1997, de amplias mayorías priistas, en los que no existía ningún tipo de contrapeso al poder de los presidentes (Casar y Marván, 2002). La exitosa asociación discursiva que logró construir López Obrador sobre los partidos tradicionales, principalmente, sobre el PRI y el PAN, a los que calificó de "ambiciosos vulgares" y los identificó como los causantes de la tragedia que vivía el país, tuvo una gran repercusión en el electorado mexicano, que no solo castigó a ambos partidos, sino que los sumió en profundas crisis identitarias, programáticas y de membresía en las cuales aún hoy se encuentran sumergidos. Esta situación ha sido, con seguridad, la principal razón por la que en los primeros 18 meses del gobierno de López Obrador se vislumbre a una oposición perdida o atolondrada.

En cuanto a la distribución del poder territorial, medido por la cantidad de estados gobernados por los diferentes partidos políticos, se

Tabla 4. Concentración de bancas en la Cámara de Diputados entre PRI, PAN y PRD y NEPp (1994-2018).

\begin{tabular}{|c|c|c|c|c|c|c|c|c|c|}
\hline Indicador & 1994 & 1997 & 2000 & 2003 & 2006 & 2009 & 2012 & 2015 & 2018 \\
\hline $\begin{array}{l}\text { Concentración } \\
\text { parlamentaria* }\end{array}$ & 98.0 & 97.0 & 93.4 & 94.6 & 87.2 & 90.20 & 86 & 74.6 & 27.2 \\
\hline NEPp Diputados & 2.29 & 2.86 & 2.78 & 3.00 & 3.57 & 3.03 & 3.55 & 4.09 & 3.18 \\
\hline NEPp Senado & 2.19 & & 2.73 & & 3.48 & & 3.33 & & 3.68 \\
\hline
\end{tabular}

Fuente: Elaboración propia con base en datos del INE y el SIL.

*Para esta Tabla la Concentración parlamentaria fue calculada con base en los porcentajes de escaños ocupados por los tres partidos tradicionales tras la creación del Instituto Federal Electoral, hoy INE (PRI, PAN y PRD).

puede observar que el empuje de López Obrador fue determinante para que siete entidades pasaran a ser gobernadas por MORENA o sus aliados, rompiendo así una dinámica en la que el PRI, el PAN y el PRD se distribuían las gubernaturas con alternancias más o menos constantes. Lo significativo es que el partido de López Obrador logró imponerse en enclaves electorales tan importantes como Ciudad de México, Veracruz o Puebla ${ }^{3}$. De esta manera, la joven formación del presidente pasó a gobernar a más de 33 millones de mexicanos en el ámbito subnacional. La heterogénea distribución partidista de los gobiernos estatales contrasta con la mayoría aplastante con la que cuenta el presidente en las cámaras del Congreso de la Unión. Este es un dato importante que no se puede soslayar, puesto que algunos gobernadores han sido las caras más visibles de la oposición al gobierno de López Obrador.

Los gobernadores Martín Orozco (Aguascalientes, PAN), Javier Corral (Chihuahua, PAN), Miguel Riquelme (Coahuila, PRI), Diego

Imagen 1. Distribución de las gubernaturas estatales en México por partido político 2012, 2017 y 2020.

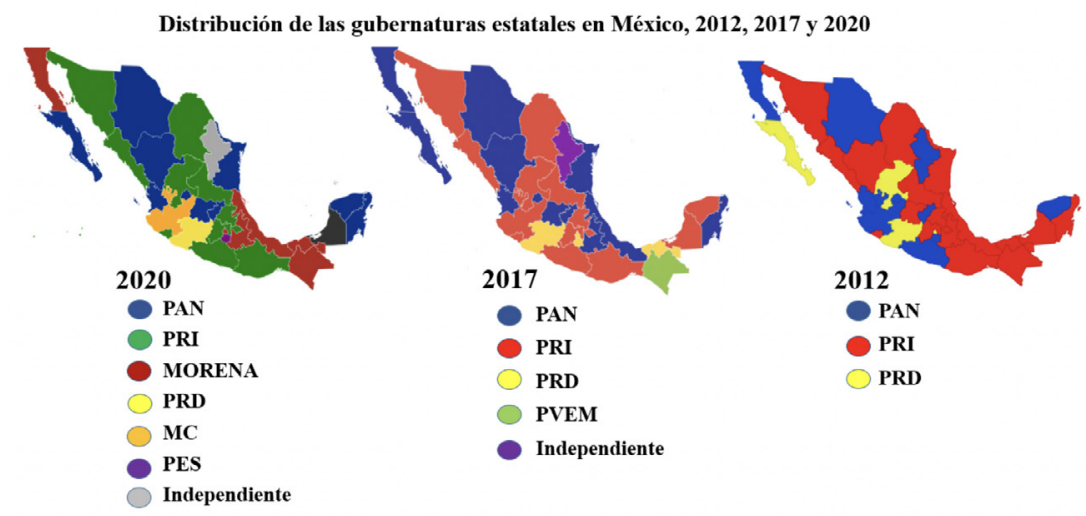

Fuente: Elaboración propia.

${ }^{3}$ La Ciudad de México había sido gobernada ininterrumpidamente desde 1997 por el PRD. El estado de Veracruz se había convertido en los últimos años en una de las entidades con los casos de corrupción más escandalosos bajo el gobierno de Javier Duarte, actualmente en prisión por el desvío de caudales públicos. El caso de Puebla es particular, pues en la elección ordinaria de 2018 la candidata del PAN, Martha Erika Alonso, venció en las urnas al morenista Miguel Barbosa, pero el 24 de diciembre de 2018 , tras diez días en el cargo, falleció en un accidente aereo junto con su esposo, el senador 
Sinhue (Guanajuato, PAN), Enrique Alfaro (Jalisco, MC), Silvano Aureoles (Michoacán, PRD), Jaime Rodríguez (Nuevo León, Independiente), Francisco Domínguez (Querétaro, PAN) y Francisco García (Tamaulipas, PAN) han sido los críticos más frontales a las políticas de López Obrador desde el inicio de su presidencia. Una clara muestra de ello en los meses recientes han sido las fricciones entre estos gobernadores y el Gobierno Federal por el manejo de la pandemia de la Coivd-19 en el ámbito sanitario y económico ${ }^{4}$. De lo que no cabe la menor duda es que la irrupción de MORENA aceleró el proceso de desalineamiento partidista que el país venía experimentando en los últimos años (Gráfica $1)^{5}$. Tal y como señalan Díaz y León (2019, p.136), el sistema de partidos mexicano da muestras de ser más fluido que hace unos años, y asumen que la pérdida de las lealtades partidistas se puede verificar en distintas dimensiones electorales como la volatilidad y la fragmentación que han crecido en las últimas elecciones y dan muestra de los cambios en la estructura del electorado mexicano.

\section{Las promesas no cumplidas de la democracia}

Gráfico 1. Desalineamiento y volatilidad electoral en México 1988-2018.

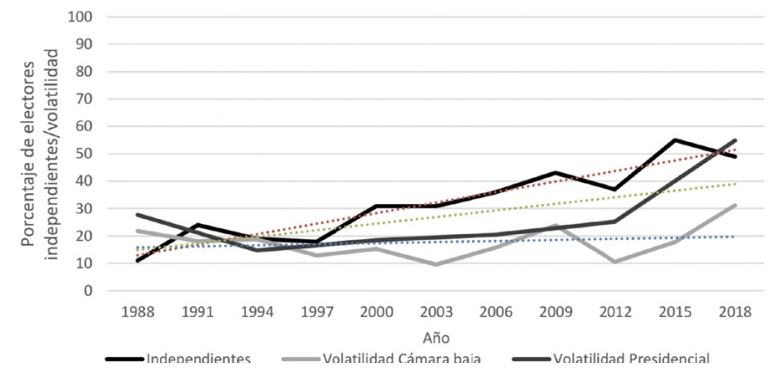

Fuente: Díaz y León (2019, p.137).

¿Cuáles fueron las condiciones previas que llevaron al triunfo de López Obrador? ¿Fue un triunfo electoral más y una alternancia dentro de una democracia o el producto del deterioro de las condiciones políticas y sociales entre 2000 y 2018 ? Las preguntas tienen sentido si se tiene en cuenta que, resumiendo el apartado anterior, López Obrador obtuvo la presidencia (a) con un partido-movimiento 'nuevo', que se constituyó apenas cinco años antes bajo su control personal; (b) los principales partidos de la transición apenas lograron triunfos marginales; (c) el PRI obtuvo el cuarto lugar en la votación, lo que significó una derrota electoral muy grave para cualquier partido en el gobierno; y (d) la corrupción política logró posicionarse como la temática central de la campaña a favor del candidato de MORENA. Pero esta coyuntura no explicaría por sí sola la alternancia hacia un movimiento que puso en jaque al sistema de partidos, por lo que se hace necesario un recuento de las condiciones de la democracia mexicana a partir del fin de la transición, sobre todo del desempeño del presidente, de su relación con los otros partidos, con los actores institucionales y con los no institucionales del sistema político mexicano.

Al menos cinco factores explican la debilidad de la democracia mexicana y la desafección a sus reglas e instituciones. Primero, el tipo de transición a la democracia, centrada esencialmente en reformas electorales. Segundo, la nula transformación de la forma de gobierno presidencial durante los primeros años de la democratización, lo que mantuvo intacta la mayoría de las reglas del (antiguo) régimen político. Tercero, el continuo desgaste de los partidos por su baja capacidad de generar representatividad, lo que derivó en polarización. Cuarto, una baja capacidad de respuesta (responsiveness) de las instituciones democráticas, desde las de control horizontal como los congresos, ejecutivos y el poder judicial, hasta las autoridades administrativas y judiciales independientes, conocidas también como órganos constitucionales autónomos, esto derivado de su proceso de burocratización y baja capacidad de modificar los comportamientos colectivos no democráticos. Por último, y como consecuencia de lo anterior, está el deterioro de aspectos centrales de la vida política mexicana, como la seguridad y la justicia.

La democracia como forma de gobierno y como sistema de vida no ha logrado arraigarse de manera profunda en la cultura política mexicana. La transición y las transformaciones del sistema político mexicano centradas esencialmente en el ámbito electoral, no han modificado sustancialmente los

${ }^{4}$ Buena parte de la confrontación entre los gobernadores y el presidente López Obrador fue propiciada por el propio mandatario tras el clima de polarización que sembró durante años, y en especial, en los meses de campaña y de transición. El enfrentamiento se agudizó en las primeras semanas luego de que López Obrador asumiera el poder, cuando en sus giras de trabajo por las entidades federativas, los gobernadores de oposición eran abucheados e increpados por los asistentes. Al poco tiempo se descubrió que estaba orquestado por las estructuras locales de MORENA (Excélsior TV, 2019).

${ }^{5}$ Autores como Norris (1997, p.86) o para el caso mexicano Díaz y León (2019) señalan que mientras el partidismo vincula con fuerza a los votantes con los partidos, el desalineamiento libera más a los votantes, quienes trasladan sus preferencias hacia otras fuerzas políticas. 
valores y las actitudes de los ciudadanos frente a la política. No es casual que la frase "el priista que todos llevamos dentro” acuñada en 1993 por el entonces dirigente del PAN, Carlos Castillo Peraza, haya sido evocada en junio del 2000 por la Senadora Beatriz Paredes -una de las dirigentes con más años dentro el PRI- para señalar la persistencia de prácticas autoritarias, precisamente cuando se supone que el sistema político mexicano debía operar de manera diferente. Sin embargo, se observa que subsisten prácticas democráticas y no democráticas que constituyen avances, pero también retrocesos. La mayoría de los mexicanos están convencidos de que la democracia, en abstracto, es la mejor forma de gobierno, pero ni la celebración periódica de elecciones ni las alternancias han disminuido el creciente malestar ciudadano (Somuano, 2007, p.943). Según el Latinobarómetro, la confianza hacia las instituciones democráticas en México continuó siendo deficitaria en 2018, tal como en años anteriores. $60 \%$ de los encuestados señalaron que tenían algún grado de confianza en los militares (58.7\% mucho o algo de confianza frente a un $40 \%$ de poca o ninguna confianza) y la iglesia $(62.2 \%$ vs $36.8 \%$ ). En contraste, el gobierno (21\% vs $77 \%$ ), el Congreso (24\% vs $71 \%$ ), los partidos políticos (15.8\% vs $83 \%$ ) y la institución electoral (42.9\% vs $54.2 \%$ ) tenían porcentajes de desconfianza muy elevados. México también apareció en 2018 como uno de los países con mayor grado de conflictividad en el contexto mundial, el Global Peace Index lo ubicó en el número 140 de entre 163 países analizados ${ }^{6}$. Así también, Transparencia Internacional lo ubicó en la posición 135 de entre 180 países como uno de los países con mayor percepción de corrupción ${ }^{7}$.

Más grave aún es que México continúe siendo uno de los países con mayor impunidad en el mundo. En el Îndice Global de Impunidad de 2018 aparece penúltimo en la lista de 59 países en que se mide la impunidad. Desde el 2012 hasta el 2018 México fue indizado con Nivel 3 por Freedom House; es decir, que las libertades de expresión y opinión están bajo riesgo y el Estado no podía asegurarlas. Mientras que en el Democracy Index 2018 de The Economist, México está clasificado como 'una democracia imperfecta', en el cual los indicadores de cultura política y funcionamiento de gobierno aparecen con los índices más bajos.
No obstante, la participación electoral es alta y llega a ser similar a la de otras democracias consolidadas. La participación aumenta significativamente en cada elección presidencial y disminuye en las elecciones intermedias o locales, pero este es un comportamiento común en los sistemas presidenciales (Payne, 2006). En resumen, en México coexisten la desafección hacia la democracia, las falencias de los gobiernos y alta participación electoral. No es una paradoja, sino que confirma la persistencia de la mentalidad presidencialista de la sociedad. Las esperanzas de mejora en el poder ejecutivo se apuestan con cada cambio.

Gráfico 2. Participación electoral en México 1994-2018.

$$
- \text { Participación -Abstención }
$$
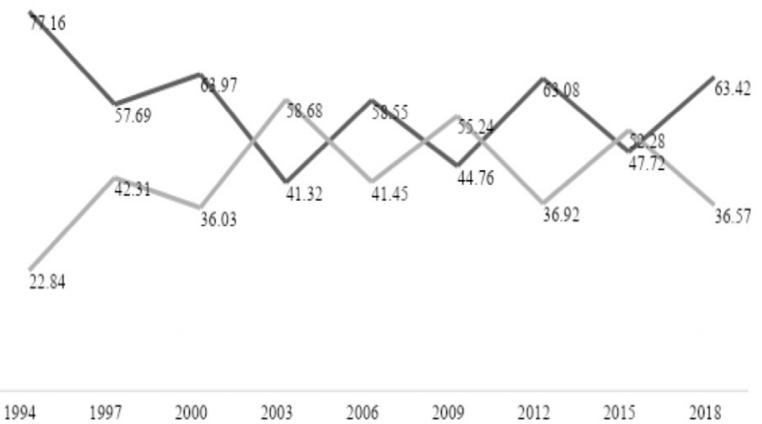

Fuente: Elaboración propia con datos de IFE e INE.

A pesar de los avances significativos en términos de una democracia electoral, todavía persisten algunas cuestiones en el ámbito político, académico e intelectual mexicano. ¿En qué medida se logró la transición a la democracia en México? Para algunos aún es un proceso inacabado, mientras que para otros no. Para unos, sus origenes son lejanos temporalmente, mientras que para otros es un proceso breve e identificable institucionalmente. Las divergencias derivan en parte de una mala periodización, pero también de una concepción de la democracia quizá muy amplia y de la cual difícilmente se pueden ver sus dimensiones totalmente cumplidas. Por ejemplo, para Loaeza (1989), los orígenes de la transición se encuentran en el movimiento estudiantil de 1968 porque desde ese año se fomentó una cultura de la participación fuera de las estructuras del Estado; para Reynoso (1998) se debe hablar de una transición

${ }^{6}$ Vid. http://visionofhumanity.org/indexes/global-peace-index/

${ }^{7}$ Vid. https://www.transparency.org/ 
sin rupturas a diferencia de otras transiciones, pues en México nunca se interrumpieron las elecciones, y el núcleo fue la pluralización del sistema de partidos; mientras que para Méndez (2006) la transición inicia en 1988 y termina con la alternancia en el 2000, es decir, que es un proceso acabado porque se consolidaron reglas que permitieron la competencia efectiva entre partidos; y finalmente, para CadenaRoa (2019), el año 2000 no fue más que un punto alto de optimismo, pues casi 20 años después, la ilusión inicial ya no existe porque en el proceso quedaron rezagadas muchas demandas que la habían impulsado.

A pesar de las divergencias, México es una democracia, pues existen las condiciones básicas que la sustentan: un sistema de partidos plural, elecciones periódicas, y competencia efectiva. Entonces ¿por qué los actores principales de su funcionamiento generan cada vez menos confianza, y en cambio, las prácticas autoritarias tienen cierto grado de aceptabilidad social? Estas preguntas permanecen de manera continua durante las dos primeras décadas del siglo XXI y las respuestas que se formularon se han convertido en el balance del estado de la democracia en México: una democracia débil.

El triunfo de Vicente Fox en el año 2000 generó muchas expectativas en todos los ámbitos políticos, económicos, sociales, culturales, etc. Fue el primer gobierno que no emanaba del PRI, por lo que la palabra "cambio" se convirtió en parte de la propaganda gubernamental. No obstante, el desempeño del gobierno fue deficiente frente a las expectativas creadas. Esto fue producto de varias condiciones, algunas causadas por el mismo Fox, ya como presidente. Para empezar, el primer gobierno de la alternancia empezó con un Congreso en el cual su partido no era mayoría. Si bien en los gobiernos presidenciales es normal que exista una coordinación entre el presidente y su partido en el parlamento, para el caso mexicano esa relación se había convertido bajo el régimen priista en una especie de sumisión del legislativo al ejecutivo. Fox trató de modificar esta inercia, pero pronto se dio cuenta de que necesitaba de su partido para gobernar. Su gobierno se caracterizó por tratar de "gerencializar" la administración pública por lo que incluyó a personas provenientes del sector empresarial, pero con nula experiencia gubernamental. No logró negociar con el corporativismo priista y le costó tratar con los partidos de oposición, lo que llevó a conflictos internos dentro de su partido sobre la selección del candidato sucesor. Uno de sus grandes problemas fue la baja capacidad de diferenciarse del régimen anterior, sobre todo de la última década del siglo $\mathrm{XX}$. De hecho, los empresarios ocuparon espacios clave en este gobierno. Probablemente el caso más emblemático fue que un líder empresarial muy cercano a la derecha conservadora y católica, Carlos Abascal, ocupara la Secretaría del Trabajo. El gobierno de Fox abrió varios frentes con la intención de diferenciarse del pasado, pero sin lograrlo. El Congreso rechazó las denominadas "reformas estructurales" referidas a los sectores laboral, fiscal y energético, y al no entender que un presidente es también Jefe de Estado, nunca logró impulsar reformas profundas a la forma de gobierno establecida en la Constitución, aunque no se puede negar que prevaleció el pluralismo y las libertades (Reveles, 2008).

La Suprema Corte de Justicia (SCJN) también tuvo una mayor presencia en dirimir las controversias constitucionales y entre poderes. Dejó de ser un actor marginal o supeditado informalmente al presidente para ocupar su lugar institucional; tan solo en el periodo del 2001 al 2006 la SCJN resolvió 825 controversias constitucionales (Espinoza, 2008, p.306). Pero Fox cometió dos errores políticos que le costaron al PAN disminuir su aceptación ante los votantes y que signaron la desilusión al final de su gobierno, además del caso de San Salvador Atenco que se explica más adelante.

Primero, entre 2004 y 2005, a partir de un litigio judicial que correspondía resolver de manera administrativa, Fox trató de impulsar el desafuero del entonces gobernador de la Ciudad de México, Andrés Manuel López Obrador. El caso dejaba ver una acción desmedida del ejecutivo y una abierta confrontación con un importante líder político de la izquierda, que tarde o temprano tendría efectos negativos para su gestión ${ }^{8}$. Este fue el momento propicio para que López Obrador iniciara una serie de movilizaciones en su defensa, pero promoviéndose al mismo tiempo como candidato a la presidencia.

${ }^{8}$ Para la mayoría de los observadores políticos, el caso estaba plagado de irregularidades, pues no se trataba de resolver una simple controversia legal entre poderes, sino que esto se aprovechó ilegítimamente para tratar de sacar de la futura contienda política a un fuerte candidato presidencial. Para un panorama de las opiniones que aparecieron en ese momento, véase Gómez Álvarez (2005). 
Al final, el gobierno de Fox tuvo que descartar los cargos (desacato a una orden judicial) contra López Obrador, pero a los ojos de una gran parte de la población quedó como un presidente que polarizó al tratar de impedir a toda costa la candidatura de un opositor. López Obrador encontró en este punto de inflexión las condiciones para presentarse como una víctima del sistema y al mismo tiempo como un candidato viable a la presidencia.

El segundo error de Fox fue tratar de imponer su candidato al PAN, cuando precisamente se esperaba que esta práctica que caracterizaba al PRI fuese diferente bajo el "gobierno del cambio". El PAN llevó a cabo una elección interna en la que las acusaciones de apoyo desde la presidencia a un precandidato, Santiago Creel, generaron divisiones dentro del partido. Al final la contienda interna la ganó Felipe Calderón Hinojosa, imponiéndose a la línea del presidente. Si bien para el partido significó la recuperación del poder de los panistas tradicionales frente a los advenedizos, también los fragmentó, por lo que el candidato llegó débil a la contienda y con poco apoyo del gobierno en turno, cuando precisamente la elección era una especie de evaluación de este.

El PAN volvió a ganar la presidencia en julio de 2006 con Calderón Hinojosa como candidato. Fueron las primeras elecciones después de la transición, pero quedaron en la historia como las más competidas, pues la diferencia entre el primer y el segundo lugar fue, como ya se señaló más arriba, menor al $1 \%$. Los cuestionamientos y la no aceptación de los resultados por el entonces candidato perdedor, López Obrador y su Coalición "Por el Bien de Todos", al grado de iniciar una movilización de resistencia civil, obligaron a las autoridades electorales a recontar una parte de los votos.

López Obrador no solo tomó por varias semanas una de las principales avenidas de la Ciudad de México, sino que también se autoproclamó 'presidente legitimo' en la Plaza de la Constitución el 20 de noviembre de 2006, unos días antes de la toma de protesta del presidente constitucional, designando una especie de gabinete de sombra. Esta acción podría haberse convertido en una manera de controlar al gobierno constitucional desde la oposición, no obstante que la Coalición por el bien de todos era la segunda fuerza en el Congreso, pero la falta de una estrategia de largo plazo hizo que la protesta quedara como un acto testimonial.
El presidente Felipe Calderón inició su gobierno con varios déficits, además del electoral. México venía arrastrando desde hace años el problema del crecimiento de la violencia e influencia del narcotráfico, los cárteles de la droga no solo habían diversificado sus mercados sino que ya controlaban amplias zonas en varios estados del país (Astorga, 2007 y 2016). La estrategia que Calderón siguió para tratar de afianzar su posición como presidente constitucional frente a un López Obrador, autodeclarado presidente legitimo, fue centrarse en la lucha contra el narcotráfico con el ejército a la cabeza. De esta manera Calderón enviaba el mensaje de que el presidente legítimo y legal es quien encabeza la administración pública federal, pero, sobre todo, quien comanda las fuerzas militares del Estado. Sin embargo, esta estrategia resultó contraproducente, apalancó marginalmente su legitimidad y, si bien no contó con mayoría legislativa en el Congreso, esto tampoco fue un obstáculo para su gobierno. Salvo las iniciativas presidenciales relativas al papel del ejército y temas fiscales, la mayoría fueron aprobadas. De hecho, durante su periodo se aprobaron reformas profundamente democráticas en materia de transparencia gubernamental (2007), en materia de justicia penal (2008) y en Derechos Humanos (2011). Pero la agenda gubernamental se supeditó al tema de la seguridad nacional sobre otros temas prioritarios, lo que tuvo resultados catastróficos (Solís, 2015). Paralelamente, el desgaste del gobierno de Calderón fue una oportunidad para que el PRI recuperara terreno en los gobiernos estatales y afianzara su dominio territorial (Ortega y Sumuano, 2015). Por ello, para las elecciones de 2012 el PRI obtuvo de nuevo la presidencia, pero no tanto por su oferta partidista y de gobierno, sino como castigo al PAN.

El regreso del PRI a la presidencia con Enrique Peña Nieto a la cabeza generó altas expectativas respecto de su gobierno, pero también varias dudas: ¿Podría considerarse un retroceso de la democracia mexicana el que volviera a gobernar el partido otrora hegemónico que apenas doce años antes había sido vencido en las urnas? ¿las otras opciones de gobierno eran tan débiles que debía aceptarse este regreso con las consecuencias que ello implicaba? En los seis años de gobierno (20122018) la percepción pública sobre el desempeño cambió marcadamente: México cayó rápidamente entre los índices de percepción de la corrupción 
de Transparencia Internacional y se colocó como el país con mayor corrupción entre los países miembros de la OCDE (Casar, 2015). Igualmente se ubicó como uno de los países con menor eficiencia de las instituciones del Estado de Derecho y con mayor impunidad en la impartición de justicia, entre otros (Nieto, 2020). No obstante haber tenido cuestionamientos relevantes en su campaña ${ }^{9}$, el gobierno de Peña Nieto inició con un alto capital de legitimidad que le permitía gobernar y operar sus reformas y políticas de forma casi holgada, diferenciándose de los dos gobiernos anteriores. No solo ganó las elecciones con un amplio margen de victoria, sino que también contaba con: (a) mayoría en las dos cámaras del Congreso, (b) mayoría en las legislaturas estatales, y (c) una aprobación presidencial que se mantuvo elevada casi dos años sin variaciones abruptas. Bajo estas y otras condiciones, en general favorables, el gobierno de Peña Nieto operó una serie de reformas bajo el rótulo de "Pacto por México". Se delinearon cinco grandes áreas: salud, economía y empleo, seguridad y justicia, gobernabilidad y combate a la corrupción. El Pacto, operado por las élites de los partidos fuera de la arena legislativa y luego impuesta a los Congresos bajo un ambiente de poca deliberación, tuvo resultados al modificar varios artículos de la Constitución. Entre las reformas más significativas se encuentran: (i) la reforma educativa, que modificó el estatus de los profesores e incorporó un sistema de evaluación de desempeño docente; (ii) la reforma en telecomunicaciones, que creó el Instituto Federal de Telecomunicaciones (IFT) e incorporó mecanismos para desmonopolizar ese sector; (iii) la reforma energética, que implicó, en términos generales, la desaparición de ciertas áreas monopólicas del Estado en la generación y distribución de energías para dar paso a concesiones a particulares; (iv) las reformas financiera, fiscal y hacendaria, que implicaron modificar más de 50 leyes y reglamentos en diversos ámbitos; y (v) las reformas políticas y electorales que crearon al INE, impulsaron la paridad en las candidaturas e incorporaron la reelección para casi todos los cargos con excepción del presidente y los gobernadores.

La oposición a las reformas movilizó a algunos sectores sociales que protestaron activamente en las calles, pero estas se aprobaron con relativa facilidad en las cámaras nacional y locales (Barrientos y Añorve, 2014). A la postre, las primeras contrarreformas del gobierno de López Obrador se orientaron en modificar la educativa y la energética, con intenciones políticas muy claras, pero poco eficientes para los sectores en cuestión. En septiembre de 2014 la desaparición de 43 estudiantes de la Escuela Normal Rural de Ayotzinapa en el municipio de Iguala en el Estado de Guerrero, fue el punto de inflexión del proceso de deslegitimación no solo del gobierno en turno, sino de todo el sistema de partidos. El gobierno fue incapaz de ofrecer respuestas confiables sobre este grave suceso, que se dio a la par con la Matanza de Tlatlaya en junio de ese mismo año. Los avances de las investigaciones abrieron dudas que fueron mermando la legitimidad de la acción gubernamental, pero también la comunicación fue poco cuidadosa, creando una sensación de incredulidad y mayor desconfianza. En democracias consolidadas cuando suceden crisis sociales graves, las autoridades más cercanas encargadas del área renuncian o se alejan para dar paso a otras personas y generar un ambiente de certidumbre e imparcialidad en la búsqueda de la verdad. En los últimos veinte años en México han sucedido eventos significativos de alto impacto que no han tenido prácticamente ningún efecto inmediato en los gobiernos, además de los casos Tlatlaya y Ayozinapa, valga citar tres sucesos más: primero, en mayo de 2006, a un mes de celebrarse las elecciones federales, en San Salvador Atenco (Estado de México), y el contexto de una mala estrategia para llevar a cabo un proceso de expropiación de tierras a campesinos para construir un aeropuerto, diversas corporaciones policiacas, federales, estatales y municipales se enfrentaron con grupos organizados que rechazaban el proyecto. No solo hubo enfrentamientos sino detenciones arbitrarias y mucho después se supo de violaciones tumultuarias a mujeres por parte de miembros del ejército. En ese entonces el gobierno federal estaba encabezado por el PAN con Vicente Fox como presidente, y el Estado de México era gobernado por Peña Nieto, quien se convertiría en presidente seis años después, y fue hasta 2010 que

${ }^{9}$ El llamado movimiento \#YoSoy132 que se activó como una crítica a la campaña del PRI en 2012 y específicamente contra su candidato originada por parte de estudiantes de una universidad privada. Centrado en gran parte en las redes sociales, este movimiento tuvo un alto impacto mediático, aglutinó a otros jóvenes universitarios que concentraron demandas de carácter coyuntural relativas a las elecciones y otras de carácter estructural relacionadas con el actuar de los medios, sobre todo televisivos, frente a los candidatos. No obstante, el movimiento fue efímero (Valdés y Maldonado, 2014) 
la Suprema Corte de Justicia decidió atraer el caso, pero solo gracias a la presión internacional y las recomendaciones de la Comisión Interamericana de Derechos Humanos (CIDH). Segundo, en junio de 2009 se incendió la guardería ABC en Sonora, estado gobernado en ese entonces por el PRI, en la que murieron 49 niños además de varios heridos, el caso dejó al descubierto una serie de corruptelas en la asignación de permisos para operar estos centros, pero ningún funcionario del nivel federal (en ese entonces del PAN) y estatal renunció. Tercero y último, el 19 de septiembre de 2017 ocurrió un sismo en la Ciudad de México. Entre las múltiples tragedias se encuentra el derrumbe de la estructura de un colegio particular, Enrique Rebsamen en el que murieron 26 personas, de las cuales 19 eran menores. La alcaldía de Tlalpan, dónde sucedió la tragedia, y la Ciudad de México estaban gobernadas por el mismo partido, el PRD, y las investigaciones nuevamente dejaron al descubierto corruptelas en los permisos de construcción y en las prácticas de verificación del funcionamiento de estos establecimientos. Al igual que en el caso anterior, ningún funcionario renunció o se retiró para permitir claridad e imparcialidad en las investigaciones.

Vistas de manera particular cada una de estas tragedias (Atenco, ABC, Ayotzinapa, Tlatlaya y Rebsamén) tienen obvias diferencias, y si bien con el pasar del tiempo la presión social ha obligado a las autoridades administrativas y judiciales a dar respuestas, lo que tienen en común es que las actuaciones iniciales de los gobernantes, en todos los casos de partidos diferentes, fueron no solo insuficientes, sino en algunos casos abiertamente irresponsables. En el imaginario colectivo no existen diferencias particulares sino más bien la idea de que todos los partidos y los políticos son iguales. La creciente desafección con la democracia mexicana se ha contenido en una serie de frases que mantienen vigente el desencanto, "si no pueden, renuncien", "estamos hasta la madre", "de todas formas no pasa nada..." o incluso movilizaciones con intenciones de buscar que los partidos sean más receptivos con las demandas de la sociedad, como pasó con el movimiento a favor del voto nulo en las elecciones intermedias de 2009 (López, 2019). Desde el caso Ayotzinapa, el gobierno del PRI encabezado por Peña Nieto empezó a mostrar signos de incapacidad para asegurar la gobernabilidad. Aparecieron nuevos escándalos: el llamado caso "Casa Blanca" y acusaciones de corrupción del entonces director de PEMEX, Emilio Lozoya, que mermaron la legitimidad en funciones del partido. A pesar de que en 2015 se implementó el Sistema Nacional Auticorrupción (SNA) con la finalidad de controlarla, pero su complejo diseño jurídico basado en la desconfianza, su falta de presupuesto específico y sus pocos instrumentos para sancionarla -pues su fuerza depende de la cooperación de todos los actores (Nieto, 2020)-, hicieron que el SNA quedara como una buena intención, pero con muy pocos resultados. Si bien en las elecciones intermedias de 2015 el PRI obtuvo menos escaños, este descenso no fue significativo pues siguió manteniendo la mayoría simple en el Congreso.

MORENA irrumpía de manera exitosa en la arena electoral. El partido de López Obrador, con una votación nada despreciable, le permitió obtener 35 escaños en la Cámara de Diputados, algo relevante para un partido casi recién creado. El partido en el poder estaba perdiendo ventaja de manera dramática ante la oposición y en 2016 , año de elecciones de seis gubernaturas en disputa, solo ganó una, Oaxaca. En 2017 se renovaron tres gubernaturas más, perdió Nayarit, pero mantuvo Durango y sobre todo el Estado de México, que es uno de los estados con uno de los mayores padrones electorales del país. En los meses previos a las elecciones de 2018, el gobierno de Peña Nieto mostraba signos muy claros de debilidad: los sondeos del momento mostraban porcentajes de desaprobación superiores al 70\%. Ningún presidente en la historia de México había obtenido en su último año de gobierno tal nivel de rechazo.

\section{Una esperanza destruida: los deslizamientos autoritarios de López Obrador}

Desde la campaña electoral, el presidente López Obrador enunció con claridad lo que serían las características de su gobierno: la lucha contra la corrupción, a la que definía como la principal causa de todos los males del país; la austeridad republicana, sobre la que insistió en que "no puede haber gobierno rico con pueblo pobre"; y el trabajo infatigable desde muy tempranas horas de la mañana. En ese sentido, resulta difícil cuestionar al presidente en cuanto a su talante por cumplir esas tres premisas en cuanto a hechos, por 
simbólicos que estos sean. Sin embargo, también es cierto que en la concreción de esos propósitos el presidente no ha dejado de causar polémicas. Hay quienes le acusan de sobreactuar algunas de sus determinaciones para alimentar el vínculo populista con sus seguidores, y hay quienes dicen que muchas de sus decisiones han carecido de sustentación técnica o incluso jurídica.

El estilo personal de gobernar de López Obrador incluye un repertorio de acciones que, por un lado, ya eran previsibles tras su paso como Jefe de Gobierno de la Ciudad de México en 2000-2005, y otra batería de maniobras que combinan rasgos populistas y autoritarios. Sobre sus acciones conocidas, se daba por sentado que López Obrador tendría la preclara intención de marcar la agenda pública al comparecer todos los días a las siete de la mañana en conferencias de prensa, tal y como fue su costumbre durante su paso por el gobierno de la capital del país.

Por otro lado, López Obrador ha manejado con éxito una especie de liturgia simbólica cuando por decisión propia determinó no viajar en el avión presidencial "porque este representaba toda la corrupción de los gobiernos neoliberales" y, por tanto, habría de hacerlo en aeronaves comerciales como cualquier persona; o bien, la decisión de no habitar la residencia oficial de Los Pinos y convertirla en un Centro Cultural de acceso público, mientras él trasladaba la vivienda presidencial al Palacio Nacional para emular a Benito Juárez, de quien siempre se ha declarado un ferviente admirador ${ }^{10}$.

Mucho se ha discutido desde hace tiempo sobre si López Obrador es o no un populista. Sin entrar en el debate sobre si los populismos son buenos o malos (Mouffe, 1999; Laclau, 2005, Mudde y Rovira, 2017; Freidenberg, 2007), en este artículo se sostiene que sí. Manteniendo la posición de Panizza (2005) para quien el populismo es un fenómeno que divide el campo político en dos: el pueblo subalterno, por un lado, y la élite por el otro (p.3). Si además asumimos que el populismo es un estilo de liderazgo sin mediación entre el líder y el pueblo (Freidenberg, 2007), no hay mucho espacio para dudar que López Obrador es una figura política con una inclinación populista.

Lo anterior es importante porque para entender el derrotero que ha ido tomando el sistema político mexicano a raíz del triunfo electoral de López Obrador en 2018, no se debe soslayar el discurso y la manera que este singular líder ha adoptado para comunicarse con su base social. En esa línea, es muy revelador el trabajo de González Tule y Restrepo (2020) quienes han logrado evidenciar el nivel de profesionalización política que ha alcanzado López Obrador en cuanto a la manera de comunicar su mensaje se refiere, en especial tras las campañas fallidas de 2006 y 2012 . Estos autores sugieren que, si ha logrado rentabilizar como nunca antes sus réditos políticos, es porque con el paso de los años ha aprendido a manejar de mejor manera diferentes recursos logísticos, estratégicos y técnicos. El uso intensivo de redes sociales, la exposición continua en medios y un lenguaje de campaña permanente son solo tres ejemplos a lo que González Tule y Restrepo hacen referencia (2020, p.153).

En esa lógica, López Obrador se ha empeñado en mostrarse como un hombre bueno y común. El lenguaje que emplea y los enemigos a los que señala un día sí y otro también han ganado la simpatía de amplias capas sociales porque su hablar es coloquial y popular, pero también ha abierto una brecha de polarización que se ahonda cada vez que desde Palacio Nacional el presidente hace alusión a sus adversarios como aprendices de carterista, chayoteros $^{11}$, conservadores, fifis ${ }^{12}$, machuchones ${ }^{13}$, mafiosos, malandrines, minoría rapaz, monarcas de moronga azul, pandilla de rufianes, pirrurris ${ }^{14}$, prensa vendida, reaccionarios de abolengo, señoritingos, tecnócratas neoporfiristas ${ }^{15}$, traficantes de influencias, traidorzuelos o zopilotes (Zaid, 2018).

Hay pocas dudas de que ese estilo no solo es intencionado, sino que forma parte de una estrategia para socavar la reputación de personas

\footnotetext{
${ }^{10}$ La decisión de eliminar el Estado Mayor Presidencial, que históricamente había sido el cuerpo de seguridad presidencial, es otra muestra del rompimiento simbólico con el que López Obrador ha querido mostrar cercanía con la gente. La expresión "a mí me cuida el pueblo" es un botón de muestra del estilo populista que López Obrador ha adoptado de manera deliberada para tener una conexión con sus seguidores.

${ }^{11} \mathrm{Se} u t i l i z a$ el término chayotero para referirse a un periodista al que se presume, o se sabe, que recibe dinero de una oficina de gobierno para inducirlo a informar a su conveniencia.

${ }^{12}$ Fifí es una palabra empleada en México para hacer referencia de manera despectiva o burlesca a las personas ricas o acomodadas, o bien a quienes tienen modales o actitudes delicadas o finas.

${ }^{13}$ Machuchón es una palabra popular utilizada en el estado de Tabasco, tierra del presidente López Obrador, para hacer referencia a los jefes. López Obrador la emplea para apelar a los empresarios o ciertos políticos de la oposición.

${ }^{14} \mathrm{La}$ palabra pirrurris es utilizada en México para hacer referencia a las personas que provienen de familias adineradas, o bien que pretenden pertenecer a la clase alta. Surge a raíz de un personaje del comediante Luis de Alba que se llamaba precisamente así.

${ }^{15}$ Con esta expresión el presidente López Obrador pretende asociar a las personas que ostentan altos grados o cualificaciones académicas con "Los Científicos" del Porfiriato.
} 
en lo individual, grupos o asociaciones a las que se consideran adversarias o sectores sociales completos a los que se catalogan como "privilegiados" y, por ende, enemigos del "pueblo bueno"16. La tónica de la agresión o la descalificación ha sido también el eje de algunas políticas públicas cuya motivación en muchos casos ha sido simplemente la obstinación de hacer algo con el afán de romper con lo que él mismo ha definido como el pasado neoliberal. Algunos ejemplos al respecto los podemos encontrar en la cancelación del Nuevo Aeropuerto Internacional de México (NAIM) o la eliminación del Seguro Popular que daba cobertura médica a millones de mexicanos sin seguridad social.

De acuerdo con lo anterior, las decisiones de López Obrador al frente del gobierno de México podrían clasificarse en cuatro tipos: (a) políticas por obstinación, que englobarian a todas aquellas decisiones que por convicción personal ha impuesto el presidente sin tomar en cuenta las posibles consecuencias; (b) políticas populistas, que serían todas aquellas orientadas a beneficiar de manera directa, sin intermediarios ni reglas de operación claras a amplios grupos sociales con fines presumiblemente electorales; (c) políticas contra la autonomía o el equilibrio de poderes en las que se pretende socavar instituciones diseñadas para funcionar como un freno o contrapeso al poder presidencial; y (d) políticas de racionalidad cuestionable, a través de las cuales el presidente premia o castiga discrecionalmente a grupos o sectores sociales sin una sólida justificación política, técnica o jurídica. Con base en lo anterior, en el Cuadro 2 se exponen algunos ejemplos de los cuatro tipos de política aquí definidos:

Cuadro 2. Tipos de política pública de López Obrador.

Tipo de política

\begin{tabular}{|c|c|c|}
\hline Por obstinación & $\begin{array}{l}\text { - Cancelación del NAIM } \\
\text { - Construcción de Aeropuerto General Felipe Ángeles (Santa Lucía) } \\
\text { - Construcción de Refinería de Dos Bocas } \\
\text { - Desaparición de Tren Maya }\end{array}$ & $\begin{array}{l}\text { - Consulta popular no legal } \\
\text { - Consulta popular no legal } \\
\text { - Consulta popular no legal } \\
\text { - Consulta popular no legal } \\
\text { - Reforma constitucional y legal }\end{array}$ \\
\hline Populistas & $\begin{array}{l}\text { - Jóvenes Construyendo el Futuro } \\
\text { - Becas Benito Juárez } \\
\text { - Pensión Bienestar Adultos Mayores } \\
\text { - Pensión Bienestar para Discapacitados } \\
\text { - Sembrando Vida } \\
\text { - Créditos a la palabra } \\
\text { - Precios de Garantía }\end{array}$ & $\begin{array}{l}\text { - Acuerdo administrativo } \\
\text { - Decreto presidencial } \\
\text { - Acuerdo administrativo } \\
\text { - Acuerdo administrativo } \\
\text { - Acuerdo administrativo } \\
\text { - Acuerdo administrativo } \\
\text { - Decreto presidencial }\end{array}$ \\
\hline $\begin{array}{c}\text { Contra la } \\
\text { autonomia o } \\
\text { el equilibrio de } \\
\text { poderes }\end{array}$ & $\begin{array}{l}\text { - Injerencia para colocar allegados políticos al frente de la Comisión } \\
\text { Reguladora de Energía (CRE), el Consejo Nacional de Evaluación de la } \\
\text { Política Social (Coneval), la Comisión Nacional de Hidrocarburos (CNH) } \\
\text { y en la Agencia de Seguridad, Energía y Ambiente (ASEA) } \\
\text { - Influencia en el nombramiento de tres nuevos ministros en la Suprema } \\
\text { Corte de Justicia de la Nación (SCJN) } \\
\text { - Reducción presupuestal al Instituto Nacional Electoral (INE), el Instituto } \\
\text { Nacional de Transparencia y Acceso a la Información (INAI), el } \\
\text { Instituto Federal de Telecomunicaciones (IFT), la Comisión Federal de } \\
\text { Competencia Económica (COFECE), la CNDH y el Poder Judicial Federal }\end{array}$ & $\begin{array}{l}\text { - Elecciones celebradas por el Senado } \\
\text { con mayoría de Morena y sus aliados } \\
\text { - Elecciones celebradas por el Senado } \\
\text { con mayoría de Morena y sus aliados } \\
\text { - Ley Federal de Presupuesto; Decreto } \\
\text { de Presupuesto de Egresos; Ley de } \\
\text { Austeridad Republicana }\end{array}$ \\
\hline $\begin{array}{l}\text { De racionalidad } \\
\text { cuestionable }\end{array}$ & $\begin{array}{l}\text { - Militarización de la seguridad pública } \\
\text { - Despliegue de Guardia Nacional para detener y expulsar a migrantes ilegales } \\
\text { - Extinción del Seguro Popular y creación del Instituto de Salud para el } \\
\text { Bienestar (INSABI) } \\
\text { - Extinción de } 281 \text { fideicomisos públicos ( } 91 \text { del Consejo Nacional de Ciencia } \\
\text { y Tecnología [Conacyt], } 48 \text { de la Secretaría de Hacienda y Crédito Público } \\
\text { [SHCP], } 19 \text { de la Secretaría de Educación Pública [SEP], entre otros) }{ }^{\star} \\
\text { - Reducción presupuestaria a los Centros Públicos de Investigación } \\
\text { - Reducción presupuestaria a la Red Nacional de Refugios para mujeres } \\
\text { víctimas de violencia } \\
\text { - Recorte de becas para estudios de posgrado } \\
\text { - Recorte de 75\% en el gasto de servicios generales, materiales y suministros } \\
\text { de la administración pública federal* } \\
\text { - Reducción salarial de los funcionarios públicos desde mandos } \\
\text { medios a superiores } \\
\text { - Suspensión del pago de aguinaldos para funcionarios públicos desde } \\
\text { mandos medios a superiores }\end{array}$ & $\begin{array}{l}\text { - Acuerdo presidencial } \\
\text { - Ley de la Guardia Nacional } \\
\text { - Decreto presidencial } \\
\text { - Decreto presidencial } \\
\text { - Decreto presidencial } \\
\text { - Ley Federal de Presupuesto; Decreto } \\
\text { - Le Presupuesto de Egresos } \\
\text { - de Presupual de Presupuesto; Decreto } \\
\text { - Decreto presidencial } \\
\text { - Decreto presidencial } \\
\text { - Decreto presidencial }\end{array}$ \\
\hline
\end{tabular}

Fuente: Elaboración propia.

*Medidas sobre las que se dio marcha atrás por presiones sociales o se matizaron como voluntarias.

${ }^{16}$ López Obrador suele dirigirse a sus seguidores y simpatizantes con esta expresión. 
La comodidad que le dan las mayorías legislativas y la ascendencia que la figura presidencial tiene sobre las y los políticos de su formación han posibilitado que López Obrador se haya venido desenvolviendo con una soltura que, difícilmente, podría haberse permitido en un contexto de gobierno dividido, de haber ganado las elecciones del 2006 o del 2012. Ese contexto favorable, en el que la oposición no solo está desarticulada, sino que está en sus mínimos, le ha permitido a López Obrador expresarse o actuar sin costos políticos aparentemente altos. Basta con echar un vistazo a las más de 26 mil "afirmaciones no verdaderas”, en promedio 71 por día (Spin, 2020) que en 18 meses ha vertido en sus conferencias matutinas para darse una idea que la imprecisión, la inexactitud o la mentira no merman (o no demasiado) la imagen presidencial, cuyos niveles de aprobación nunca, hasta ahora, han estado por debajo de 60 por ciento de la opinión pública, de acuerdo con las mediciones de Alejandro Moreno para el periódico El Financiero (2020).

Imagen 2. Aprobación presidencial de López Obrador (diciembre del 2018 a mayo del 2020).

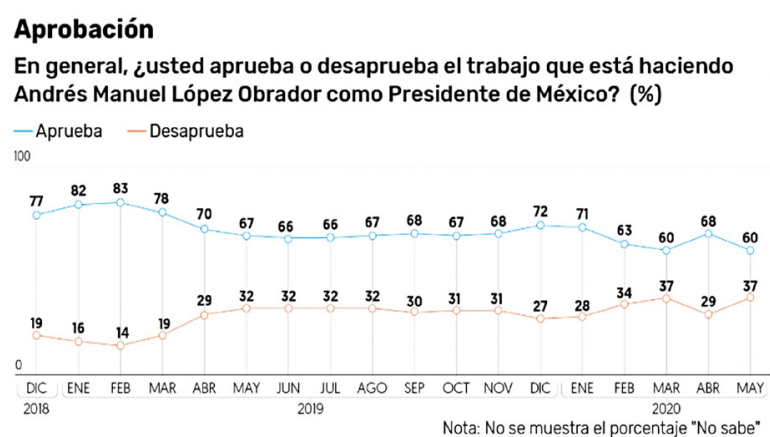

Fuente: El Financiero (2020).

Esta percepción positiva sobre el desempeño del presidente parece ser "indestructible" ${ }^{17}$, incluso tras episodios polémicos y puntuales como: (a) la captura y liberación de Ovidio Guzmán; (b) el saludo del presidente a la madre de Joaquín "El Chapo" Guzmán; (c) los enfrentamientos con los grupos feministas; (d) el incremento de los homicidios y feminicidios; (e) la caída de la economía; (f) el cuestionable manejo de la crisis del C ovid-19; o incluso (g) la polémica visita a Donald Trump.

\section{Oposición ausente y oligarquias pragmáticas}

La oposición partidista quedó muy desdibujada a partir del triunfo de López Obrador y su movimiento. El PAN subsistió como baluarte opositor, pero muy debilitado ante la opinión pública, mientras que el PRI prácticamente quedó sin fuerza en el ámbito legislativo, aunque con un número significativo de gubernaturas estatales, y el PRD casi a punto de desaparecer. Por otro lado, los grupos de poder económico, con algunas excepciones como la Confederación Patronal Mexicana (COPARMEX), así como una gran parte de los medios de comunicación, se movieron pragmáticamente hacia la izquierda como una estrategia para beneficiarse de las políticas dirigidas desde la Presidencia. En muy poco tiempo aparecieron en diversos diarios nacionales y locales 'nuevos' columnistas que orientaron sus opiniones acríticamente hacia el Gobierno Federal. Bajo estas condiciones, la relación gobierno-oposición no opera de manera horizontal entre el poder ejecutivo federal y el Congreso, sino de dos maneras: la primera, yuxtapuesta en el nivel federal, entre gobernadores estatales y el ejecutivo federal, en 2020 de los 32 estados que conforman el país, 24 eran gobernados por un partido diferente al del presidente (como se aprecia en la Imagen 1); la segunda, que opera de forma diagonal entre grupos de poder fáctico (empresarios y medios) que apoyan abiertamente al presidente y a su gobierno, frente a aquellos que son críticos, generando una situación de polarización que a mediados de 2020 es más profunda $^{18}$.

Las dificultades para que las oposiciones tengan espacios formales $\mathrm{y}$ eficientes para convertirse en contrapeso del poder en México se encuentran en la rigidez del sistema de partidos, pues desde 2003 se ha encarecido el acceso al mismo. Primero se burocratizó el proceso de creación de los partidos (2003), ya que inicialmente debían constituirse como agrupaciones políticas nacionales (APN), se aumentó el número de afiliados y la distribución territorial, más estados y más distritos uninominales en los cuales deberían tener presencia. En 2007-2008 se abrió otro proceso de reformas electorales como consecuencia

\footnotetext{
${ }^{17}$ López Obrador empleó la expresión "soy indestructible" en su campaña hacia la presidencia. "Mi escudo protector es la honestidad; soy políticamente indestructible: AMLO" (La Jornada, 2018)

18“Se está con la transformación o en contra de ella: AMLO" (Aristegui Noticias, 2020).
} 
de la complicada elección del 2006. Se eliminaron las APN, pero la posibilidad de formar partidos se limitó a cada seis años. Esas reformas modificaron aspectos importantes de las leyes que regulaban el financiamiento a partidos políticos, y que en años anteriores habian generado dos efectos perniciosos: partidos políticos que solo se formaban como negocios financiados con recursos públicos o, por el contrario, partidos grandes que se aprovechaban de las lagunas legales para recibir financiamiento que al final no era auditable. El caso más emblemático fue "Amigos de Fox", una estructura paralela al PAN, que gestionó entre 1998 y el año 2000 la candidatura de Vicente Fox a la presidencia. Para algunos esto representaba corrupción, pues se utilizaron recursos privados para incidir de manera ilegítima en un proceso político, pero para otros simplemente fue aprovechar los espacios que la ley no trataba. Como sea, el tema del financiamiento público a los partidos es un tema recurrente y en 2007 se trataron de corregir los mecanismos de asignación. Entre las acciones más importantes estuvo la equidad en el acceso a los recursos entre partidos y los montos a recibir en años no electorales, así como la fiscalización. También se ampliaron los mecanismos de democracia directa, como la iniciativa popular, el plebiscito y el referéndum, así como las candidaturas independientes (Córdova, 2014). En 2013-2014 se promovió otra serie de reformas más significativas fueron la reelección de senadores, diputados federales y locales, y se incluyó la paridad entre hombres y mujeres en las candidaturas, un tema que ya venía ganando terreno con la incorporación de las cuotas. Pero nuevamente se incorporó una reforma que va en contrasentido de mejorar la representación, pues se aumentó la barrera de acceso de $2 \%$ a $3 \%$ de los votos que los partidos debían obtener para mantener el registro y acceder a la distribución de escaños plurinominales. Por otro lado, la regla de la mayoría sigue siendo percibida como la más deseable, pero en el diseño que se aplica en México la hace una fórmula que excluye y disminuye la representación.

¿Por qué a pesar de estas reformas políticas la ciudadanía mexicana mantiene una relación ambigua con la democracia? Las respuestas derivan del diseño institucional de la democracia mexicana, que no ha logrado vincularse con los intereses de la sociedad en sentido amplio, y probablemente han sido soluciones que siguen quedando en la esfera de los intereses de las élites políticas y no de la ciudadanía en general. Basta señalar tres ejemplos:

1. La aparición y desaparición de partidos políticos, y la concentración partidista centrada en apenas tres partidos políticos nacionales. Desde el año 2000 y hasta el 2018 se crearon doce nuevos partidos políticos los cuales participaron en elecciones y obtuvieron pocos votos, pero mientras duraron, recibieron generosas participaciones por parte del Estado y su desempeño en la democracia mexicana fue, por lo general, poco significativo, salvo contados casos: Democracia Social (19992000), Partido de Centro Democrático (1999-2000), Partido Alianza Social (19982003), Partido de la Sociedad Nacionalista (1998-2003), Partido México Posible (20022003), Partido Fuerza Ciudadana (20022003), Partido Liberal Mexicano (20022003), Partido Socialdemócrata (2005-2009), Partido Nueva Alianza (2005-2018), Partido Humanista (2014-2015), y Partido Encuentro Social (2014-2018). Varios de estos partidos tuvieron una vida de solo uno o dos años y compitieron una vez en elecciones. Otra gran parte sobrevivió gracias a las alianzas con los grandes partidos. Finalmente, el Partido Convergencia (1999-2011), el cual se transformó en Movimiento Ciudadano (MC), siguiendo las tendencias en América Latina de sustituir el término partido como una manera de intentar contrarrestar la desafección hacia el mismo. Los grandes partidos (PRI, PAN, y PRD) han acaparado la mayoría de los votos, mientras que el PT y el PVEM son partidos que han sobrevivido por sus alianzas pragmáticas con el resto, pero sin representar ni ser una alternativa política real. Este panorama de pocas opciones partidarias muestra un sistema de partidos de pluralismo moderado pero rígido y liderado por élites políticas con baja capacidad de renovarse.

2. La difícil operación de los mecanismos de democracia directa. Desde que se creó la Iniciativa legislativa ciudadana en 2012 y hasta el 2018, solo se habían presentado 11 , de las cuales apenas una tuvo éxito y se publicó (La Ley General de Responsabilidades 
Administrativas, mejor conocida como Ley 3 de 3), mientras que tres quedaron pendientes (es decir, congeladas) y el resto fueron desechadas o retiradas. Con el antecedente de pocas experiencias exitosas de democracia directa a nivel local, este mecanismo fue integrado al texto constitucional en 2012, pero fue hasta 2014 que se publicó una la Ley de Consulta Popular. En ese mismo año se promovieron tres consultas, una sobre el salario mínimo impulsada por el PAN, otra (impulsada por el PRI) sobre la reducción del número de diputados $\mathrm{y}$ senadores, en específico los de representación proporcional, mientras que el PRD proponía someter a consulta la reforma energética. Con unas reglas de operación bastante complicadas para que fueran activadas por los ciudadanos, este mecanismo ha sido utilizado por los partidos para promover sus iniciativas o someter a consulta temas que serían de difícil aprobación. López Obrador y su partido MORENA utilizaron el mecanismo de consulta popular de manera ilegítima e ilegal en 2018 y 2019. En 2018, incluso antes de tomar posesión, sin ningún sustento legal y con la participación de menos de un 1\% del padrón electoral se decidió suspender las obras del Nuevo Aeropuerto Internacional de México. Igualmente, en 2019 también el partido MORENA utilizó el mecanismo de la consulta popular de manera sesgada para tratar de legitimar una maniobra inconstitucional que buscaba mantener más tiempo en el poder al gobernador de Baja California, Jaime Bonilla, cuestión que luego fue resuelta en contra por la Suprema Corte de Justicia de la Nación.

3. El uso sesgado de mecanismos orientados a fortalecer el sistema de representación. Las candidaturas independientes, por ejemplo, presentadas como un mecanismo estrella terminaron como un fracaso pues no constituyen alternativas políticas ni derivan de un clivaje que requiera espacio político en el sistema de representación. Al contrario, se convirtieron en instrumentos de miembros de partidos que cuando no lograban una candidatura terminaban presentándose como independientes, arrastrando los votos de su clientela electoral (Laguna y Solís, 2017). Publicada igualmente la reforma en 2012, junto con otros mecanismos que trataron de ampliar la democracia directa, las candidaturas independientes generaron muchas expectativas. Sin embargo, los estudios han demostrado que son excepciones los casos en los que un ciudadano obtiene una candidatura independiente y logra ganar. Muy al contrario, son los 'ciudadanos con carrera política previa' o aquellos que renuncian de un día a otro de su partido los que pueden acceder a una candidatura independiente. Más aún, resulta muy complicado competir frente a las estructuras partidistas (Laguna y Solís, 2017). En las elecciones de 2015 lograron su registro 143 candidatos independientes para todos los niveles: municipal, estatal y nacional, pero solo ganaron 6, mientras que en 2018 compitieron 213, siete para gobernador, 38 para diputados federales, cuatro para el Senado, 62 como diputados locales y 162 para presidentes municipales, pero solo ganaron 18 en estos últimos comicios (Vidal, 2019). El complicado y cerrado sistema de partidos, y el uso sesgado de los mecanismos de participación ciudadana han generado dinámicas que más que ampliar las bases de la democracia han facilitado la oligarquización beneficiando a las élites políticas tradicionales, por lo que es difícil percibir cambios en el vértice del poder.

Finalmente, es necesario mencionar que el diseño del presidencialismo le da a las oposiciones partidistas y no partidistas, un papel marginal en el control del gobierno. Si la mayoría de las decisiones provienen del ejecutivo, y si los partidos de oposición no generan alternativas de gobierno, la sociedad termina por asumir que son innecesarios y más aún, que deberían desaparecer. Por ello es recurrente que cada vez que un partido tiene mayoría en el Congreso trate de eliminar la representación proporcional. Así lo hizo el PAN cuando era gobierno en el 2008, pues propuso eliminar los diputados plurinominales. Un año antes, en el 2007 el PVEM propuso reducirlos a 150. En 2017 el PRI era gobierno y propuso eliminarlos totalmente del Senado y reducirlos a 100 para la Cámara de Diputados. Y en el 2019, 
MORENA ya en el gobierno, propuso reducir a 400 los escaños de la baja, de los cuales solo 100 deberían ser plurinominales, además de eliminar los 32 senadores de representación proporcional. En todos los casos, la argumentación va en al menos dos sentidos: el ahorro en el presupuesto; es decir, se tasa el valor de la representación, no bajo criterios democráticos sino económicos, o bajo criterios de agilizar las negociaciones, es decir, bajo el falso criterio de que la representación ampliada puede ser un mecanismo que dificulta la gobernabilidad.

En cualquier caso, de lo que se trata es de afectar precisamente la representación política, la cual bajo el diseño actual no ha logrado mejorar la percepción de la democracia. No es el espacio aquí para señalar cuáles mecanismos sí podrían ayudar a superar los déficits de la democracia mexicana, como cambiar la fórmula de asignación de escaños, las listas abiertas, el voto preferencial o alternativo, entre muchas otras opciones, pero sí se debe tener en cuenta que el sistema presidencial basado en la lógica de la mayoría o de las mayorías en un país multicultural, bastante extenso y con problemáticas altamente diferenciadas entre los estados que lo componen, solo ha cristalizado los problemas derivados de la (mala) representación, más que resolverlos.

\section{A manera de conclusión}

Los factores que hacen débil a la democracia mexicana muestran que, a pesar de los cambios políticos, las reformas estructurales en varios sectores clave del funcionamiento de Estado, pero sobre todo las alternancias políticas, no han sido suficientes para fomentar una cultura política democrática, porque a la par del proceso de democratización, las élites políticas y económicas se han reacomodado para mantener sus ámbitos de influencia sin modificar radicalmente el statu quo. Mientras que, por otro lado, la clase política, sobre todo a nivel local, mantiene prácticas políticas clientelares, sustentadas en demandas coyunturales y buscando siempre mantener un control político no democrático (Tejera et. al., 2014). La paradoja es que la llegada tan esperada por muchos de un movimiento de izquierda a la presidencia no ha modificado estas relaciones, sino que las ha profundizado, debilitando aún más la democracia mexicana. El triunfo de Andrés Manuel López
Obrador en 2018 fue el colofón de casi dos décadas en las que, si bien se produjeron transformaciones importantes en el sistema político mexicano, cabe reconocer que estas fueron más bien de corte político, algunas de ellas tardías, y por lo general estuvieron orientadas a mantener un bajo recambio en las élites en el poder, afectando la representación política y erosionando la credibilidad de los partidos. Estos han sido asociados como los responsables de los graves problemas que atraviesan a la nación: violencia e inseguridad, corrupción, desempleo, pobreza o precarización económica. Las promesas incumplidas de la democracia, parafraseando a Norberto Bobbio, fueron en gran medida las que catapultaron al actual presidente López Obrador, quien capitalizó mejor que nadie el clima de descontento social imperante a través de lo que Alberti definió como "movimentismo".

López Obrador representa para millones de mexicanos la última esperanza de reconducir o regenerar la vida pública del país. Es previsible que, de no cumplir con las expectativas puestas en él, y en lo que se ha empeñado en autonombrar como la "Cuarta Transformación", el desalineamiento partidista termine siendo tan grande que el sistema de partidos quede al borde del colapso, como ha ocurrido en otros casos de la región como Perú y Venezuela. También hay que subrayar que si López Obrador y su partido-movimiento MORENA triunfaron rotundamente en las elecciones de 2018, es porque no ha existido una diferencia sustancial entre las y los políticos de los partidos tradicionales. Estos, gobernando a nivel federal, estatal o municipal se han caracterizado por el continuismo de las prácticas políticas del pasado hegemónico priista, las prácticas autoritarias para disuadir o marginar a sus rivales políticos, la falta de responsabilidad política $\mathrm{y}$, en algunos casos, la rapacidad.

De allí la abrumadora confianza ciudadana depositada en el gobierno de López Obrador y su partido. Se espera que cambie el estado actual, sin embargo, no se puede soslayar que el propio López Obrador y muchos de quienes le rodean en sus círculos más cercanos, provienen de las trincheras del viejo régimen priista que se distinguió por una subordinación monolítica al líder, la inclinación ante el poder, el prebendarismo entre amigos, la corrupción, los conflictos de interés y el tráfico de influencias. Aunque López Obrador proclame repetidamente el fin de la corrupción por la vía 
del discurso o del decreto, basta con mirar las irregularidades que en sus primeros dieciocho meses de gobierno rodean a funcionarios o personajes destacados muy cercanos, como Manuel Bartlett, director de la Comisión Federal de Electricidad; Rocío Nahle, secretaria de Energía; Irma Eréndira Sandoval, secretaria de la Función Pública; Zoé Robledo, director del IMSS; Ana Gabriela Guevara, directora de la Comisión Nacional del Deporte, o Napoleón Gómez Urrutia, Senador, líder minero que estuvo prófugo de la justicia por años.

López Obrador, al igual que sus predecesores, han desarrollado lo que Cosío Villegas (1974) definió como un "estilo personal de gobernar". Pero en su caso, se ha distinguido por su impronta populista, traducida en profusos dichos y hechos; y en cuanto a su performance como gobernante se ha caracterizado por tener un estilo variopinto en el tipo de políticas que ha adoptado: (a) por obstinación; (b) populistas; (c) contra la autonomía o el equilibrio de poderes; y (d) de racionalidad cuestionable. La combinación de su liderazgo carismático, el tipo de políticas que ha desplegado y el estilo impositivo de las mismas en sus primeros meses de gobierno, de acuerdo con la clasificación de Richardson (1982), es lo que ha hecho pensar a muchas y a muchos si ello no es un peligroso coqueteo con el autoritarismo. Esto sobre todo cuando López Obrador ha otorgado un gran protagonismo a las Fuerzas Armadas en tareas tan disímiles como la construcción del nuevo aeropuerto de Santa Lucía, la conducción, en los hechos, de la Guardia Nacional, la vigilancia de las fronteras, el control de las aduanas portuarias y el apoyo complementario ante la emergencia de la pandemia de la COVID-19.

De acuerdo con los indicadores clave de comportamiento autoritario establecidos por Levitsky y Ziblatt (2018), si bien López Obrador no encaja con plenitud en los cuatro supuestos o dimensiones por ellos propuesto, sí es posible afirmar que lo hace parcialmente en al menos dos de ellas: (a) el rechazo o débil aceptación de las reglas democráticas del juego; y (b) la negación de legitimidad de los adversarios políticos. Sin afán alguno de caer en la hipérbole, no es descabellado encontrar similitudes puntuales en cuanto a rasgos autoritarios se refiere, entre López Obrador $\mathrm{y}$ otros líderes que no son de izquierda y llegaron igualmente por la vía de las urnas con estrategias de confrontación, como Donald Trump, Jair Bolsonaro o Nayib Bukele, por citar tan solo tres ejemplos en América. De hecho, no se puede pasar por alto la manera particular que el presidente Trump ha tenido para referirse a su homólogo mexicano al llamarlo Juan Trump por la empatía que el mandatario estadounidense dice tener con López Obrador.

Ante el retraimiento o disipación de la oposición en el país, no hay duda que dicho espacio ha sido ocupado tímidamente por algunos gobernadores, aunque quienes con mayor decisión y visibilidad han jugado ese papel han sido los grupos feministas, las víctimas de la violencia o los padres de familia de niños con cáncer cuyos tratamientos fueron suspendidos como consecuencia de las acciones de la austeridad republicana. Todos estos y otros grupos han sido 'ninguneados' por López Obrador, fomentando la lógica de "amigo-enemigo". Mientras esto ocurre, no ha perdido el tiempo para afianzar una amplia red clientelar bajo el auspicio de programas sociales 'sin intermediarios' cuyas reglas de operación y confección de censos han sido seriamente criticadas. Basta con mencionar que 97\% de las regiones en las que operan los llamados Servidores de la Nación coinciden exactamente con los distritos electorales federales (Hernández Estrada, 2019, p.58). Como se ha señalado en este artículo, muchas de las prácticas políticas no democráticas han sido fomentadas en diversos momentos y con particulares diferencias por todos los gobiernos desde la transición, pero si algo caracteriza al de López Obrador es su intensidad abiertamente antidemocrática, bajo el disfraz casi obsesivo del uso de la palabra "pueblo", como si con ello las prácticas fueran justificadas. En suma, a veinte años de la transición, México no solo es una democracia débil, sino asediada

\section{Referencia}

Alberti, Giorgio. (julio de 1991). Democracy by Default, Economic Crisis and Movimientismo in Latin America. Ponencia. En: Congreso mundial de la Asociación Internacional de Ciencia Política. Buenos Aires, Argentina.

Alcántara Sáez, Manuel. (2020) América Latina Vota (201719): elecciones en el marco de una democracia fatigada. En Alcántara Sáez, Manuel (Dir.). América Latina Vota (2017-2019). Madrid: Tecnos, pp. 531-550.

Aristegui Noticias. (6 de junio del 2020). Se está con la transformación o en contra de ella: AMLO. Disponible en: https://aristeguinoticias.com/0606/mexico/ 
se-esta-con-la-transformacion-o-en-contra-de-ella-amlo

Astorga, Luis.

(2016). El siglo de las drogas. Ciudad de México: Random House.

(2007). Seguridad, traficantes y militares. Ciudad de México: Tusquets.

Barrientos, Fernando y Añorve, Daniel. (2014). México 2013. Acuerdos, reformas y descontento. Revista de Ciencia Política, Vol. 34, Núm. 1, pp. 221-247.

Cadena-Roa, Jorge. (2020). ¿En qué momento se malogró la democratización de México? El malestar con la representación en México. México: UNAMFicticia, pp. 123-162.

Carrera Troyano, Miguel y Solís Delgadillo, Juan Mario. (2012). Balance socioeconómico de más de dos décadas de ortodoxia: ¿por qué no crece México? En Martí i Puig, Salvador (Ed.) ¿Adónde chingados va México? Madrid: Catarata, pp. 163-183.

Casar, María Amparo y Marván, Ignacio (Coords). (2002). Gobernar sin mayoría. México 1867-1997. México, D.F.: Taurus.

Casar, María Amparo. (2015). México: anatomía de la corrupción. México: CIDE, IMCO.

Casullo, María Esperanza. (2019) ¿Por qué funciona el populismo? Buenos Aires: Siglo XXI Editores.

Córdova Vianello, Lorenzo. (2014). Sistema electoral y sistema de partidos. Pluralismo político en las reformas constitucionales en materia electoral. En Casar, María Amparo y Marván, Ignacio (Coords.) Reformar sin mayorías. La dinámica del cambio constitucional en México: 19972012. México: Taurus, pp. 217-258.

Cosío Villegas, Daniel. (1974). El estilo personal de gobernar. México, D.F.: Cuadernos de Joaquín Moritz.

Díaz Jiménez, Oniel y León Ganatios, Luis. (2019). Los escenarios electoral e ideológico en el sistema de partidos mexicano. Una mirada posterior a la elección 2018. Ciudad de México: Tirant Lo Blanch.

Díaz Jiménez, Oniel Francisco. (2019). El sistema de partidos mexicano después de la elección crítica de 2018. Desalineamiento, cartelización y desinstitucionalización. Estudios sobre las Culturas Contemporáneas, XXV(5),33-71. [fecha de Consulta 5 de Julio de 2020]. ISSN: 1405-2210. Disponible en: https://www.redalyc. org/articulo.oa? $\mathrm{id}=316 / 31659683003$

El Universal, Diario. (11 de febrero del 2009). Desconocen al Partido Verde. Disponible en: https://archivo. eluniversal.com.mx/nacion/165665.html

Espinoza Toledo, Ricardo. (2008). El gobierno de Vicente Fox: el cambio como promesa, la continuidad como realización. En Francisco Reveles Vázquez (Coord.) El gobierno panista de Vicente Fox. La frustración del cambio. México: UNAM, pp. 297-323.

Excélsior TV. (2019). PRI y PAN acusan a Morena de organizar abucheos a gobernadores [Archivo de video]. Disponible en: https://www.youtube.com/ watch? $=4 \mathrm{uJRXalPSY0}$

Freidenberg, Flavia. (2007). La tentación populista. Madrid: Sintesis.

Gómez Álvarez, Pablo (Coord). (2005). Voces contra el desafuero de Andrés Manuel López Obrador. México: Grupo Parlamentario del PRD en la LIX Legislatura

González Tule, Luis Antonio y Restrepo E., Néstor Julián. (2020). Campañas presidenciales de 2018 en México: nivel de profesionalización, equipo de campaña y estrategias políticas. América Latina Hoy, 84: 137-161.

Hernández Estrada, Rafael. (2019). Servidores de la Nación. La operación política del gobierno de la 4T. Ciudad de México: PRD.

Katz, R., y P. Mair. (1995). Changing Models of Party Organization and Party Democracy: The Cartel Party. Party Politics, I: 1-28

La Jornada, Periódico. (9 de febrero del 2018). Mi escudo protector es la honestidad; soy políticamente indestructible: AMLO. Disponible en: https:// www.jornada.com.mx/2018/02/09/politica/009n1pol

Laclau, Ernesto. (2005). La razón populista. Buenos Aires: Fondo de Cultura Económica.

Laguna López, Adán y Solís Delgadillo, Juan M. (2017). Las candidaturas independientes en México: una nueva vía para el reciclaje político. Toluca: IEEM.

Levy Algazi, Santiago. (2018). Under-rewarded efforts: The elusive quest for prosperity in Mexico. Washington, D.C.: Banco Interamericano de Desarrollo.

Loaeza, Soledad (1989). México 1968: los orígenes de la transición. Foro Internacional, Vol. XXX, Núm. 1, pp. 66-92.

Loaeza, Soledad. (2008). Entre lo posible y lo probable. La experiencia de la transición en México. México: Planeta.

López Leyva, Miguel A. (2019). “De 'Si no pueden, renuncien' a 'Estamos hasta la madre': los sintomas sociales de la desafección política en México". En Cadena-Roa, Jorge y López Leyva, Miguel A. (Coords.) El malestar con la representación en México México: UNAM-Ficticia, pp. 163-192.

Magar, Eric. (2014). Los contados cambios al equilibrio de poderes. En Casar, María Amparo y Marván, Ignacio (Coords.) Reformar sin mayorías. La dinámica del cambio constitucional en México: 
1997-2012. México: Taurus, pp. 259-294.

Martínez Hernández, Aldo Adrián. (2020). Las elecciones del fin de ciclo: el giro a la izquierda en México 2018 y el cambio en el sistema de partidos. En Alcántara Sáez, Manuel (Dir.). América Latina Vota (2017-2019). Madrid: Tecnos, pp. 357-390.

Mattiace, Shanan. (2019). México 2018. AMLO's Hour. Revista de Ciencia Política, Vol. 39, Núm. 2, pp. 285-311.

Méndez de Hoyos, Irma. (2006). Transición a la democracia en México. Competencia partidista y reformas electorales 1977-2003, México: FontamaraFlacso.

Merino, Mauricio. (2003). La transición votada. Crítica a la interpretación del cambio político en México. México: Fondo de Cultura Económica.

Moreno Brid, Juan Carlos y Ros Bosch, Jaime. (2010). Desarrollo y crecimiento de la economía mexicana. México, D.F.: Fondo de Cultura Económica.

Morlino, Leonardo. (2008). ¿Regímenes híbridos o regímenes en transición? Revista Sistema, Núm. 207, pp. 3-22.

Mouffe, Chantal. (1999). El retorno de lo político. Barcelona: Paidós.

Mudde, Cass y Rovira, Cristóbal. (2017). Populism. A Very Short Introduction. Oxford: Oxford University Press.

Nieto Morales, Fernando. (2020). El Legado del "sexenio de la corrupción”: los retos del Sistema Nacional Anticorrupción. Foro Internacional, Vol. LX, Num. 2, pp. 683-716

Norris, Pippa. (1997). Electoral Change in Britain since 1945. Oxford: Blackwell.

Ortega Ortiz, Reynaldo Y. y Sumuano Ventura, Ma Fernanda. (2015). El periodo presidencial de Felipe Calderón Hinojosa, Foro Internacional, Vol. 55, Núm. 1, pp. 5-15.

Panizza, Francisco. (2005). Populismo como espejo de la democracia. México, D.F.: Fondo de Cultura Económica

Reveles Vázquez, Francisco (Coord). (2008). El gobierno panista de Vicente Fox. La frustración del cambio. México: UNAM.

Reynoso, Víctor. (1998). Las razones y las formas de una transición gradual: México 1988-1994. En Dutrenit, Silvia (Coord). Huellas de las transiciones políticas. Partidos y elecciones en América Latina, México: Instituto Mora.

Solís Delgadillo, Juan Mario, Cerna Villagra, Sarah P. y Díaz Jiménez, Oniel F. (2017). El sistema político mexicano. En Curso de Ciencia Política. Ciudad de México: Senado de la República, pp. 519-547.

Solís Delgadillo, Juan Mario. (2014). Radiografía de la violencia: justicia y seguridad ciudadana en América Latina. En Problemas de la seguridad nacional: contexto para México y Latinoamérica. Monterrey: Lezcano y Garza Editores, pp. 181-208.

Somuano, Ma. Fernanda. (2007). Evolución de valores y actitudes democráticos en México (19902005), Foro Internacional, Vol. XLVII, Núm. 4, pp. 926-944

Spin. (2020). Conferencias matutinas de AMLO. Infografía 28, mayo 2020. Disponible en: http://www.spintcp. com/conferenciapresidente/infografia-28/

Tello Díaz, Carlos. (2007). 2 de julio. La crónica minuto a minuto del día más importante de nuestra historia contemporánea. México, D.F.: Planeta.

Tejera Gaona, Héctor; Castro Domingo, Pablo; y Rodríguez Domínguez, Emanuel (Coords). (2014). Continuidades, rupturas y regresiones. Contradicciones y paradojas de la democracia mexicana. México: UAM-Conacyt-Juan Pablos.

Ugalde, Luis Carlos. (2008). Así lo viví. Testimonio de la elección presidencial de 2006, la más competida en la historia moderna de México. México, D,F.: Grijalbo.

Valdés Vega, Ma. Eugenia y Maldonado Montes, Josefina. (2014). El reclamo democrático del movimiento \#YoSoy132. En Continuidades, rupturas y regresiones. Contradicciones y paradojas de la democracia mexicana. México: UAM-ConacytJuan Pablos, pp. 299-335.

Vidal Correa, Fernanda. (2019). La fortaleza de las candidaturas independientes y sus oportunidades de competencia frente a los partidos políticos en México. Revista mexicana de ciencias políticas y sociales, 64(235), 427462 .

Zaid, Gabriel. (25 de junio del 2018). AMLO poeta. En Letras Libres. Disponible en: https://www.letraslibres.com/ mexico/politica/amlo-poeta 